\title{
Colombia: Selected Issues
}

This Selected Issues paper for Colombia was prepared by a staff team of the International Monetary Fund as background documentation for the periodic consultation with the member country. It is based on the information available at the time it was completed on December 19,2008. The views expressed in this document are those of the staff team and do not necessarily reflect the views of the government of Colombia or the Executive Board of the IMF.

The policy of publication of staff reports and other documents by the IMF allows for the deletion of market-sensitive information.

\footnotetext{
Copies of this report are available to the public from

International Monetary Fund $\bullet$ Publication Services

700 19th Street, N.W. • Washington, D.C. 20431

Telephone: (202) 623-7430 • Telefax: (202) 623-7201

E-mail: publications@imf.org • Internet: http://www.imf.org
}

\section{International Monetary Fund Washington, D.C.}





\section{INTERNATIONAL MONETARY FUND}

\section{COLOMBIA}

\section{Selected Issues}

Prepared by Lisandro Abrego, Benedict Clements, Enrique Flores, Herman Kamil (all WHD), Daniel Leigh (FAD), Marcos Souto (MCM), and Mercedes Vera Martin (SPR)

Approved by the Western Hemisphere Department

December 19, 2008

Contents

I. The Colombian Banking Sector_-A Contingent Claims Analysis .............................................

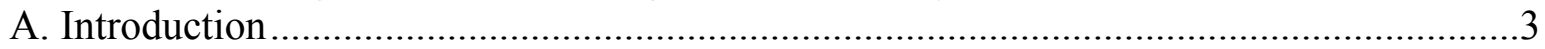

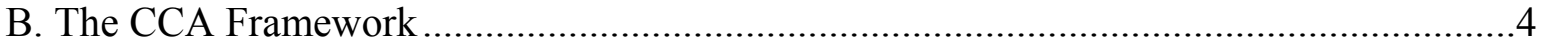

C. Some Background on the Colombian Banking System ...............................................5

D. Implementing the CCA Approach for Colombia .................................................. 7

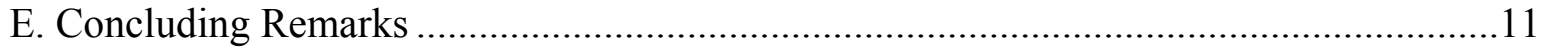

II. An Assessment of Financial Sector Indicators For The Colombian Corporate Sector ...............14

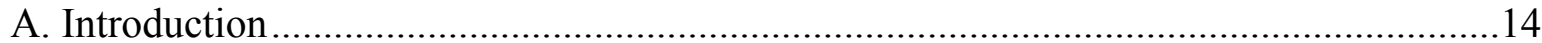

B. Structural Features of the Corporate Sector in Colombia ............................................15

C. Balance Sheet and Profitability Analysis ................................................................. 17

D. Assessing the Foreign Exchange Exposure of the Corporate Sector ............................20

E. Market-Based Assessments of Selected Corporates in Colombia.................................21

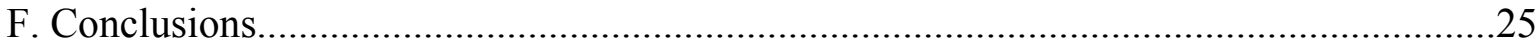

III. Policy Options for Dealing with External Shocks: Insights from the GIMF for Colombia .......29

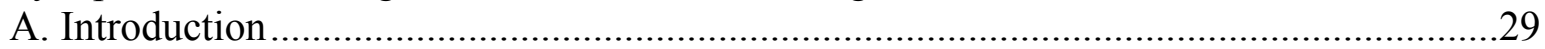

B. The Model ................................................................................................................. 30

C. Macroeconomic Effects of External Shocks and Alternative Policy Responses .............33

D. The Role of Fiscal Policy Under Different Financing Conditions.................................38

E. Summary of Policy Implications ..................................................................... 41

IV. Are Capital Controls Effective in the $21^{\text {st }}$ Century? The Recent Experience of Colombia .......43

A. Introduction .......................................................................................................4

B. Database and Stylized Facts on Capital Flows and Exchange Rates ............................44

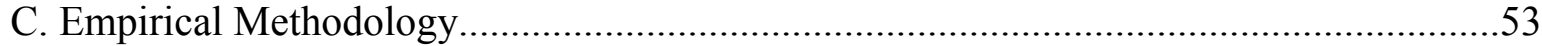

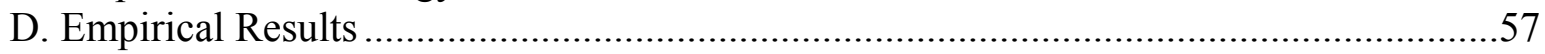

E. Conclusions and Suggestions for Future Research .................................................64 
Tables

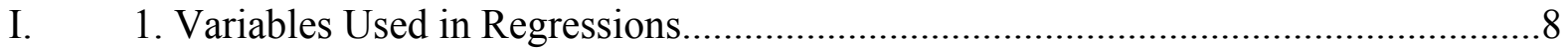

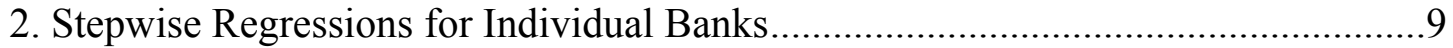

3. Stepwise Regression for the Banking System .................................................... 10

4. Dynamic Panel Results .................................................................................. 10

5. Results for Granger Causality Tests ............................................................... 11

II. $\quad$ 1. Sectoral Characteristics of the Corporate Sector, 2002-07 .................................16

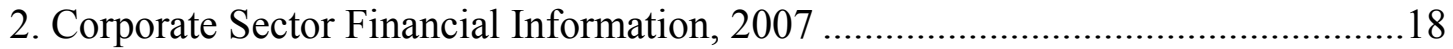

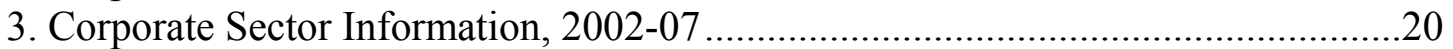

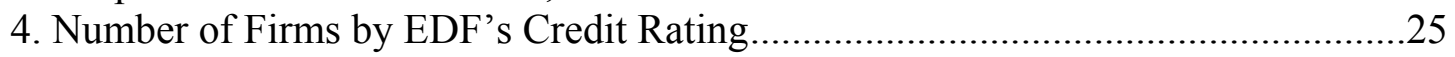

5. EDF Distribution by Credit Quality.....................................................................25

IV. 1. Private Capital Flows Before and After Capital Controls ...................................49

2. Impact of Capital Controls on Non-FDI Private Capital Flows .............................58

3. Impact of Capital Controls on Foreign Borrowing and Drawdown on Residents'

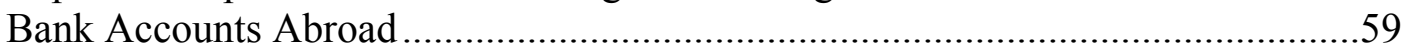

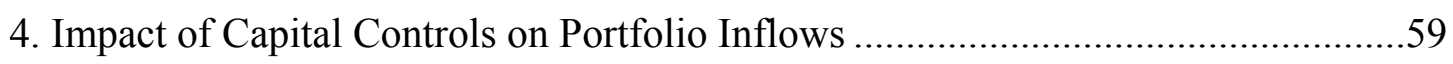

5. Impact of Capital Controls on the Exchange Rate - Full Sample .........................61

6. Impact of Capital Controls on the Exchange Rate — Sub-Sample ........................63

Figures

II. 1. Expected Default Frequencies ....................................................................22

2. EDF's for Selected Corporates ...........................................................................24

III. 1. Macroeconomic Response to a Decline in the Demand for Colombian Exports

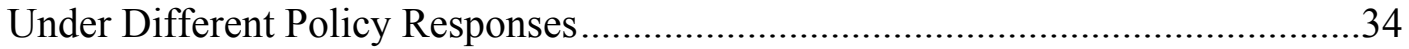

2. Macroeconomic Response to a Decline in World Growth ......................................36

3. Macroeconomic Response to Temporary Increase in Risk Premium ........................37

IV. 1. Private Capital Flows Before and after Capital Controls.......................................50 


\section{The Colombian Banking Sector-A Contingent Claims Analysis ${ }^{1}$}

\section{A. Introduction}

1. The effects on macroeconomic and financial shocks on the banking system are of great interest to policymakers. Given the important linkages between the real and the financial sectors, particularly during volatile periods, a quantification of these effects may prove useful to anticipate potential changes in the level of risk faced by financial institutions. An option for estimating such effects is a modeling framework of banking system risk, combined with econometric models incorporating relevant macroeconomic and financial sector variables.

2. This paper uses contingent claims analysis (CCA) to assess risks to the Colombian banking sector. The CCA approach is based on the estimation of the default probability by an entity on its obligations, and is widely used by rating agencies to assess creditworthiness in the corporate sector. The paper builds on recent work using the CCA methodology undertaken in other Latin American countries (e.g., Gray and Walsh, 2008; Souto, 2008). It uses Moody's-KMV estimates of expected default frequencies (EDFs) for Colombian banks, which are constructed with market-based data. ${ }^{2}$ The advantage of this indicator is that it incorporates a forward-looking, collective view of risk by market participants. Such a forward-looking element cannot be captured by traditional balance sheet measures of bank vulnerabilities. In addition, EDFs directly incorporate the effects of volatility on risk, and thus better capture the nonlinearities that are particularly important during periods of distress.

\section{The paper estimates the effects of changes in selected macroeconomic and} financial variables on default probabilities for a sample of Colombian banks. The sample includes five banks for which market-based default probabilities are available. These account for over one-half of the Colombian banking sector. The paper estimates step-wise regressions for both individual banks and the aggregate system, as well as panel regression for the pooled data for individual banks. Reflecting the heterogeneity of the financial institutions included in the sample, results from step-wise regressions differ significantly across banks, although they generally show the vulnerability of banks to changes in key economic activity variables and financial market conditions. The paper also tests for Granger causality between default probabilities and a traditional indicator of bank credit vulnerability (the ratio of non-performing loans to total loans-NPL ratio) for the banking sector as a whole. The results show that EDFs are a leading indicator of NPL ratios.

\footnotetext{
${ }^{1}$ Prepared by Marcos Souto and Lisandro Abrego.

${ }^{2}$ Other CCA-based indicators of risk include distance-to-distress and expected losses given a default. Gray and Walsh (2008) presents a brief description of these indicators and estimates for the Chilean banking system.
} 
4. Our findings are comparable to those from similar studies undertaken for other emerging markets in Latin America. Using market data, Gray and Walsh (2008, on Chile), and Souto, Tabak, and Vazquez (2008, on Brazil) find that bank soundness is significantly related to macro-financial variables, while also finding evidence of heterogeneity between banks. Blavy and Souto (2008, on Mexico) using risk indicators estimated with book value data for the Mexican banking sector find equally consistent results. In a similar vein, Souto (2007) finds that CCA indicators capture well the episodes of bank stress in Uruguay.

5. The paper is organized as follows. Section B presents a brief description of the CCA methodology. Section C provides some background on the Colombian banking system. Section D discusses the data and results of the CCA analysis. Section E presents some concluding remarks.

\section{B. The CCA Framework}

6. The CCA offers some distinct advantages over other approaches to vulnerability analysis. ${ }^{3}$ First, the CCA takes balance sheet information and combines it with current and forward-looking financial market prices to compute risk-adjusted, marked-to-market balance sheets (i.e. asset values). Using financial market price information to derive forward-looking risk-adjusted balance sheets is a significant advantage compared to an analysis based on past balance sheet information. Second, the CCA distinguishes itself from other vulnerability analysis in that it incorporates market volatility when estimating credit risk. Volatility is crucial in capturing nonlinear changes in risk, especially during times of stress, when small shocks can gain momentum and trigger systemic repercussions.

7. Under the CCA model, a firm's equity can be viewed as a (junior) contingent claim on the residual value of its assets. In the event of default, all the firm's assets are used to pay the senior stakeholders (e.g. debt holders); otherwise equity holders receive the difference between the value of assets and debt. Thus, the equity of the firm can be seen as a call option on the residual value of the firm's assets. This

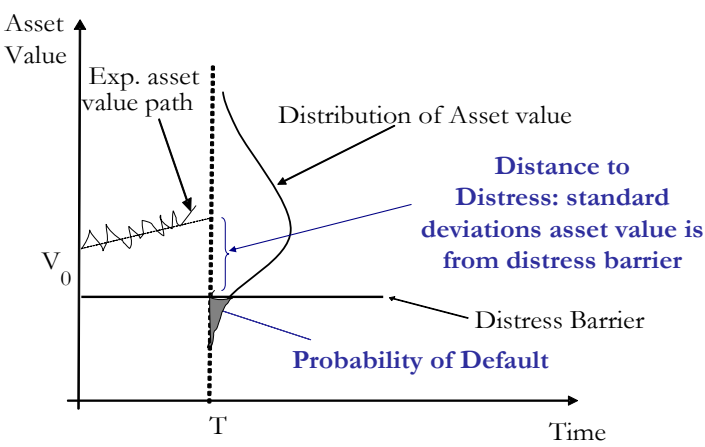
framework enables a rich characterization of a firm's (or sovereign's) balance sheet.

\footnotetext{
${ }^{3}$ See Gapen, Gray, Lim and Xiao (2004) for a more in-depth discussion of the advantages and disadvantages of the CCA approach.
} 
8. With information on the market value and volatility of equity and the value of debt, it is possible to estimate the implied value for assets and volatility through the Black and Scholes option formula. Firms are assumed to default whenever the value of assets fall below a given "distress" barrier. It is then possible to estimate a set of credit risk indicators, including distance-to-distress, default probability, credit spread, and expected losses in the event of default.

9. At the same time, the CCA is only a tool to help understand credit risk, and certain caveats need to be kept in mind. First, as with any model that uses market information, the quality of the output of the CCA depends on how well market information reflects changes in fundamentals. If markets are imperfect, or react excessively to changes in fundamentals, the CCA indicators may overstate risk. It should also be noted that the CCA's capacity to capture off-balance sheet risks is also imperfect, as it depends on how well these are incorporated into equity prices.

\section{Some Background on the Colombian Banking System}

10. Financial intermediation in Colombia has grown considerably in recent years and compares well with regional levels. The recovery from the crisis of the late 1990s and strong economic growth have contributed to a sizeable expansion of financial intermediation during the current decade. As of mid-2008, credit to the private sector was equivalent to 33 percent of GDP, over 10 percentage points up from the beginning of the decade, and slightly above the average for the largest economies in the region. Credit growth in Colombia was very strong in 2005-07 but decelerated significantly over the last year, following substantial monetary tightening by the Banco de la República aimed at containing inflationary pressures and protecting financial sector stability. ${ }^{4}$ Consumer credit expanded particularly fast, and currently accounts for slightly under

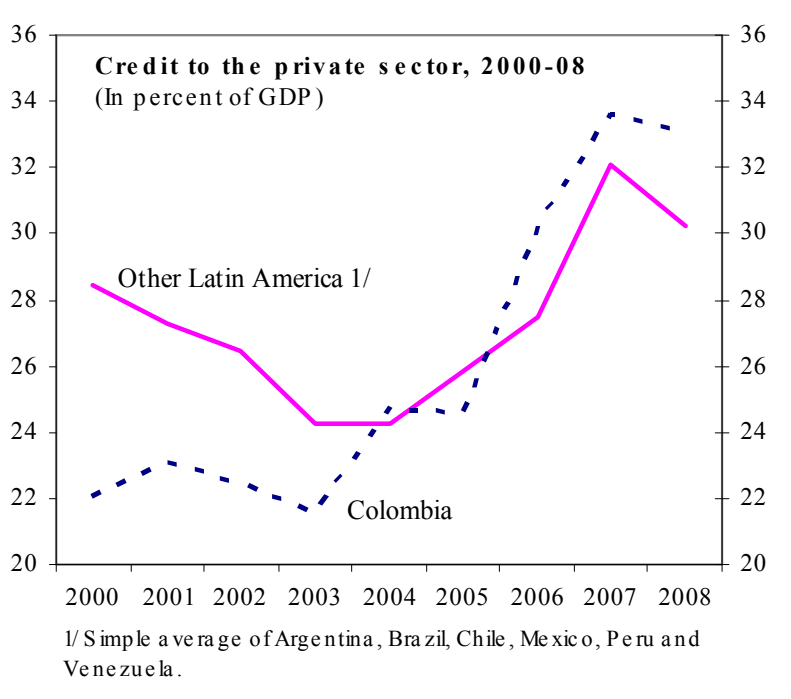
30 percent of total credit to the private sector.

\footnotetext{
4 The Banco de la República raised its policy rate by 400 basis points, to 10 percent, between April 2006 and July 2008. It also increased marginal reserve requirements in May 2007, although these were lowered in late 2008 as a preventive measure to ensure adequate levels of liquidity in the system.
} 


\section{The Colombian banking system exhibits somewhat high levels of concentration.}

The system is made up of 17 institutions, all but one privately-owned. In mid-2008, the 5 largest banks accounted for about 70 percent of the system's total assets and liabilities. This level of concentration is comparable to that in other large Latin American countries.

12. Foreign presence in the sector is relatively modest. As of mid-2008, subsidiaries of foreign banks accounted for slightly over 20 percent of the system's total assets and liabilities. While featuring a rising trend over the last few years, this level of foreign participation is significantly smaller than the average for the region, which currently exceeds 30 percent.

13. Financial soundness indicators for the banking system are solid. The ratio of nonperforming loans (NPLs) to total loans has risen over the last couple of years - especially for consumer credit_ but remains low at about 4 percent, and NPLs are well provisioned. ${ }^{5}$ The system is well capitalized, with risk-adjusted capital adequacy well above minimum requirements ( 9 percent) for most banks. Despite the recent rise in NPL ratios, indicators of profitability have remained strong, with returns on assets hovering around $2 \frac{1}{2}$ percent over the last year. Liquidity levels appear adequate, with short-term assets exceeding short-term liabilities by a comfortable margin. With the pace of economic activity decelerating rapidly from the high levels of 2006-07, ${ }^{6}$ credit risk has become an important source of risk in the banking system (Banco de la República, 2008).
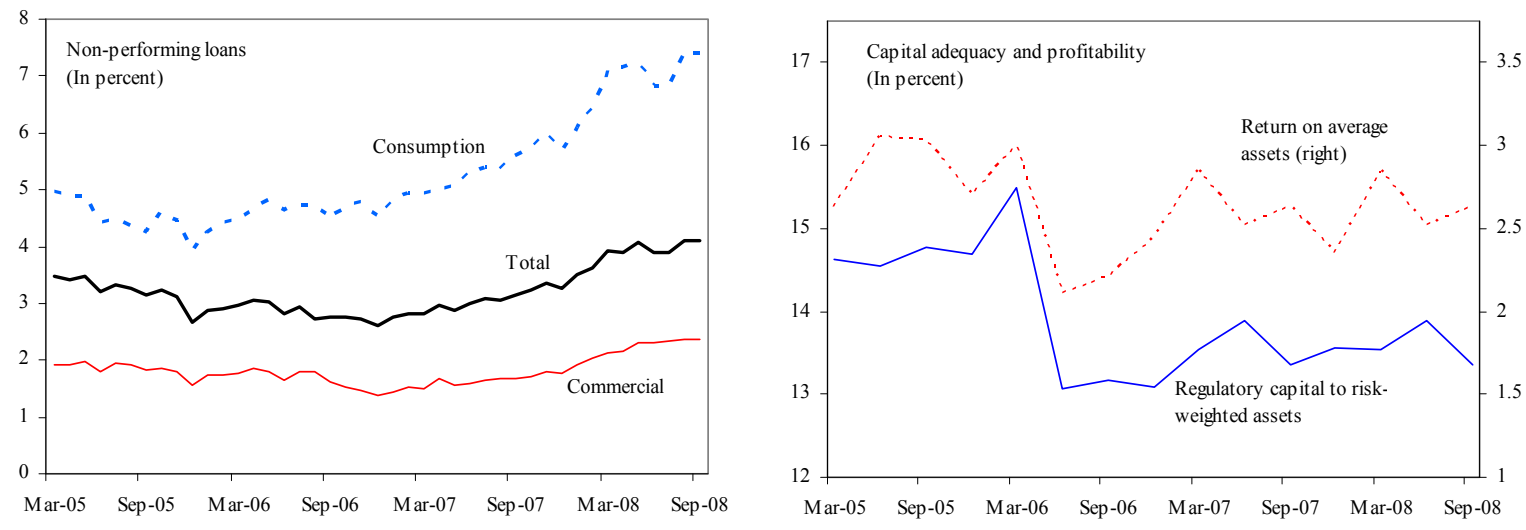

\footnotetext{
5 The data referred to in this paragraph are for September 2008.

${ }^{6}$ GDP growth declined from an average of 71/4 percent in 2006-07 to about 4 percent in the first half of 2008 . It is expected to decelerate further in 2009 , against the backdrop of weaker global growth and less buoyant domestic demand conditions.
} 


\section{Implementing the CCA Approach for Colombia}

\section{Data}

\section{Available market-based EDF estimates for Colombia cover about half of the}

banking system over a relatively short time period. Moody's-KMV estimates of EDFs are available for five banks (two domestically-owned institutions and three foreign subsidiaries), which as of mid-2008 accounted for about 55 percent of total banking system assets and liabilities. The data series starts in the fourth quarter of 2003. While data on EDFs are available on a monthly (and even daily) frequency, this paper uses a quarterly series, given that information for key macroeconomic variables affecting bank risk are available only on a quarterly basis.

15. Estimated EDFs are highly correlated with traditional measures of bank risk.

The market-based EDF data show a decline in bank risk through the first quarter of 2006, and a subsequent upward movement of risk. These trends are strongly correlated with the evolution of the banking system's non-performing loan ratio over the sample period.

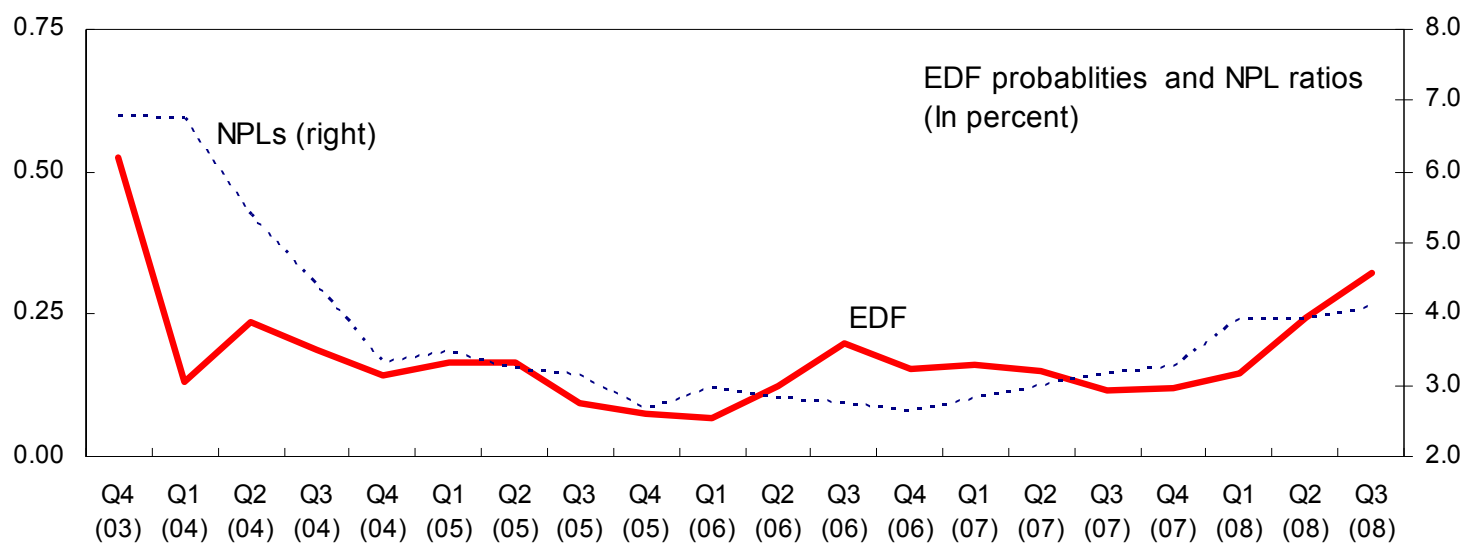

Source: Creditedge (Moody's-KMV). 


\section{Main results}

\section{Stepwise regressions reveal that economic activity and financial market conditions have an important impact on EDFs, but with significant differences across}

banks. OLS stepwise regressions were ran over time series for individual banks and a set of macrofinancial variables (Table 1). We started with the full set of variables and allowed the regressions to extract the variables for which the covariate coefficient were found to be significant at the 10 percent level or greater. The optimal model specification differed across banks (Table 2). Among the most salient results are the following:

- $\quad$ An increase in the Colombian stock market index (IGBC) is associated with a decrease in the individual KMV EDF for two of the five banks. This is consistent with the CCA framework, in which a higher equity/capital would result in an improved credit risk profile for banks. For one bank, an increase in risk aversion (as measured by the VIX index) is associated with a decrease in the KMV EDF. This would be consistent with the view that, as the degree of risk aversion increases, investors would shift their investment positions away from Colombia and into safer assets.

- $\quad$ For another bank, real GDP growth is associated with an improvement in the KMV EDF, reflecting the impact of real sector 'good periods' on the financial sector.

- $\quad$ The differences in the optimal specification are surprising. The fit of the equations is good, even though the same variable is rarely significant across different banks. These results mirror those of Gray and Walsh (2008).

Table 1. Variables Used in Regressions

\begin{tabular}{llll}
\hline $\begin{array}{l}\text { Dependent Variable: } \\
\text { Bank KMV EDF } \\
\text { System KMV EDF }\end{array}$ & & \\
Covariates: & & & \\
Bank & Bank & & \\
Specific & System & Macrofin & Macrofin \\
\hline - Bank Cred. Growth & - Syst. Cred. Growth & - Domestic & Foreign \\
- Bank NPL & - System NPL & - FX Rate & - VIX \\
& & - Dom. Int. Rate & - S\&P 500 \\
& & - CPI Inflation & - Comm. Prices \\
& & - Unemp. Rate & \\
& & - Real GDP growth & \\
& & - EMBI Spread &
\end{tabular}




\section{A stepwise regression for the aggregate banking system also underscores these} macro-financial linkages (Table 3). The results suggest that the Moody's-KMV EDF indicator would improve (decrease) if: (i) real GDP growth increases; (ii) the Colombian stock market increases (revealing an increase in equity/capital); (iii) credit growth increases (potentially associated with the higher returns that banks can reap from these loans); ${ }^{7}$ and (iv) the U.S. S\&P500 index decreases (in which case investors may look for better returns in other markets such as Colombia).

Table 2. Stepwise Regressions for Individual Banks

\begin{tabular}{|c|c|c|c|c|c|}
\hline & Bank 1 & Bank 2 & Bank 3 & Bank 4 & Bank 5 \\
\hline$\overline{\text { VIX }}$ & $0.002 * *$ & & & & \\
\hline IGBC & & & $-0.004 * * *$ & $-0.002 * *$ & \\
\hline FX Rate & & & $0.009 * *$ & & \\
\hline Real GDP Growth & & & & & $-0.046 * *$ \\
\hline Bank NPL & & & & $-0.132 *$ & \\
\hline Domestic Int. Rate & & $9.636 * *$ & & & \\
\hline US Federal Rate & & $0.081 *$ & & & $-0.181 * * *$ \\
\hline R-Square & $31.2 \%$ & $33.4 \%$ & $68.6 \%$ & $37.8 \%$ & $55.0 \%$ \\
\hline F-Stat & $6.81 * *$ & $3.51 *$ & $15.32 * * *$ & $4.25 * *$ & $8.54 * * *$ \\
\hline
\end{tabular}

Note: $* * * * *, *$ means that the regression coefficients are statistically different than zero at the $1 \%, 5 \%$, and $10 \%$ significance levels respectively.

\footnotetext{
${ }^{7}$ There are two counterbalancing forces at play here. On one side, an increase in credit growth is usually associated with an increase in NPLs, which would reduce banks' capital and deteriorate the credit risk indicator. On the other side, these loans also earn a substantial rate of return that may more than compensate for the NPL-related losses (and increase in provisioning). That seems to be the case in Colombia, which would also be consistent with the view that banks have continued to pursue an aggressive policy of credit extension during most of the sample period.
} 
Table 3. Stepwise Regression for the Banking System

\begin{tabular}{lc}
\hline & $\begin{array}{c}\text { Bank } \\
\text { System }\end{array}$ \\
\hline Real GDP Growth & $-0.009 * *$ \\
System Credit growth (LC) & $-0.002 *$ \\
IGBC & $-0.003 * * *$ \\
S\&P 500 & $0.007 * * *$ \\
\hline R-Square & $82.9 \%$ \\
\begin{tabular}{l} 
F-Stat \\
\hline $\begin{array}{l}\text { Note: } * * *, * *, * \text { means that the regression } \\
\text { coefficients are statistically different than zero at the } \\
1 \%, 5 \%, \text { and } 10 \% \text { significance levels respectively. }\end{array}$
\end{tabular}
\end{tabular}

18. Panel regressions reveal similar results. In order to use all available market-based information for Colombian banks, we ran a linear dynamic panel-data model with fixed effects, based on the Arellano and Bond (1991) GMM estimator. The results (Table 4) show that: (i ) an increase in the Colombian stock market index is associated with a decrease in EDFs, as predicted by the underlying framework; (ii) an increase in NPLs is also associated with a decrease in EDFs, consistent with the result found for credit growth in the stepwise regression for the aggregate baking system; and, finally, (iii) an increase in the interest rate is contemporaneously associated with an increase in EDFs. It is important to clarify that the interest rate used was the U.S. interest rate for the 3-month T-bill (proxy for the "risk-free" asset) plus the EMBI spread. Thus, an increase in this interest rate is consistent with a expected deterioration in the banks' EDFs.

Table 4. Dynamic Panel Results

\begin{tabular}{lr}
\hline & \multicolumn{1}{c}{ Bank EDF } \\
\hline Bank EDF (lag1) & $0.185 * * *$ \\
Domestic Int. Rate & $1.670 * * *$ \\
IGBC & $-0.002 * * *$ \\
& $-0.015 * * *$ \\
Bank NPL & $\begin{array}{l}\text { Note: ***,**,* means that the regression } \\
\text { coefficients are statistically different than }\end{array}$ \\
zero at the $1 \%, 5 \%$, and $10 \%$ significance \\
levels respectively.
\end{tabular}


19. Causality tests reveal that the system EDF is a leading indicator of the system NPL ratio, with a one-quarter lag. Granger causality tests fail to reject the hypothesis that the system EDF cannot explain the system NPL at the one percent confidence level. ${ }^{8}$ At the same time, the tests indicate that the NPL ratio does not explain future movements in the EDF. These results suggest that the system EDF provides useful information beyond what is contained in the NPL ratio and can thus be useful in early warning systems.

Table 5. Results for Granger Causality Tests

\begin{tabular}{lcc}
\hline Equation & Excluded & Chi-Square \\
\hline System EDF & System NPL & $16.36 * * *$ \\
System NPL & System EDF & 3.53 \\
\hline Note: $* * *, * *, *$ means that the regression coefficients are \\
statistically different than zero at the $1 \%, 5 \%$, and $10 \%$ \\
significance levels respectively.
\end{tabular}

\section{E. Concluding Remarks}

\section{Contingent claims analysis can be a useful tool to assess risk in the Colombian} financial sector. When compared to traditional measures of bank risk, EDF estimates capture well developments in banking system over the period for which EDF market-based data are available. Importantly, Granger causality analysis shows that the EDFs are a leading indicator of traditional measures of bank risk. Given the availability of EDF estimates on a high frequency, CCA could thus be a helpful tool in improving the monitoring of the financial system's health.

\section{Empirical estimates show that macroeconomic and financial shocks have an} important bearing on banking sector vulnerabilities. Econometric results show that a positive shock to economic growth reduces risk for the banking system as a whole. Interest rate increases and downward movements in the domestic stock market are associated with a rise in bank risk. Results for individual banks vary widely, reflecting the heterogeneity of the Colombian banking sector. However, financial institutions in general show vulnerability to changes in key domestic macroeconomic variables, as well as to changes in domestic and international financial market conditions. These results are consistent with findings for other Latin American countries in studies using CCA.

\footnotetext{
${ }^{8}$ This result holds even when we exclude the observations for 2004, a period when the system EDF clearly seems to cause the system NPL.
} 
22. There is scope to improve and extend the application of the current analysis of the Colombian banking system. The quality of the estimates for the relationship between macroeconomic and financial market variables, and banking sector risk could be strengthened through the use of longer time series. This could be done by using higher frequency data, which are readily available for all variables included in the various models, except for economic growth. The latter could, however, be proxied by combined forward-looking indicators of economic activity currently produced on a monthly basis in Colombia (e.g., industrial production, retail sales, etc.). ${ }^{9}$ Another approach could be to use principal component analysis to summarize the impact on bank risk of changes in diverse macrofinancial variables, building, for example, on work done for Chile by Gray and Walsh (2008).

\footnotetext{
${ }^{9}$ Principal component analysis could be used to produce a leading indicator of economic activity that incorporates existing indicators.
} 


\section{References}

Arellano, M., and S. Bond, 1991, "Some tests of specification for panel data: Monte Carlo evidence and an application to employment equations," Review of Economic Studies 58: 277-297.

Blavy, R. and M. R. Souto, 2008, "Examining Macrofinancial Linkages in the Mexican Banking Sector Using Book Value Credit Risk Indicators," Selected Issues Paper in the 2008 Article IV Consultation for Mexico, forthcoming.

Banco de la República, 2008, Reporte de Estabilidad Financiera. Bogotá: Banco de la República. September issue. Available at: http://www.banrep.gov.co/publicaciones/pub_es_fin.htm

Gapen, Michael T., Dale F. Gray, Yingbin Xiao, and Cheng Hoon Lim, 2004, "The Contingent Claims Approach to Corporate Vulnerability Analysis: Estimating Default Risk and Economy-wide Risk Transfer," IMF Working Paper 04/121 (Washington: International Monetary Fund), available on the web at: http://www.imf.org/external/pubs/ft/wp/2004/wp04121.pdf

Gray, Dale F. and J. Walsh, 2008, "Factor Model for Stress-testing with a Contingent Claims Model of the Chilean Banking System," IMF Working Paper 08/89 (Washington: International Monetary Fund), available on the web at: http://www.imf.org/external/pubs/ft/wp/2008/wp0889.pdf

Souto, M. R., 2008, "Has the Uruguayan Financial System Become More Resilient to Shocks? An Analysis Adapting the Merton Framework to a Country Without Equity Market Data," in Piñón Farah, M., G. Gelos, and A. López Mejía, Macroeconomic Implications of Financial Dollarization: The Case of Uruguay, IMF Occasional Paper No. 263 (Washington: International Monetary Fund), available on the web at: http://www.imf.org/external/pubs/cat/longres.cfm?sk=21761.0

Souto, M.R., B. M. Tabak, and F. Vazquez, 2008, "Linking Financial and Macroeconomic Factors to Stress-Test Credit Risk Indicators for Brazilian Banks.” Central Bank of Brazil Working Paper, forthcoming. 


\section{An ASSESSMENT OF FinANCIAL SECTOR IndiCATORS For The COLOMBIAN CORPORATE SECTOR ${ }^{1}$}

\section{A. Introduction}

1. Like many emerging market countries, Colombia has been affected by the ongoing turmoil in global financial markets. The resulting decline in asset prices, depreciation of the exchange rate, and increase in financing costs have important implications for the balance sheets of both the public and private sector, including corporates.

2. The capacity of the corporate sector to respond to these shocks will depend not only on the size of the shocks, but also on the initial health of the financial sector at the onset of the crisis. In this chapter, we provide an assessment of financial sector indicators in the Colombian corporate sector, relying mainly on balance sheet and profitability analysis for a substantial number of firms. Foreign exchange exposure in 2007 is also analyzed for a smaller number of corporates. While the balance sheet and income statement analysis provides a good sense of the health of the corporate sector, it does not incorporate a forwardlooking risk assessment from market participants. To address this, we also look at expected default frequencies (EDFs) under the Contingent Claims Approach (CCA), using Moody's KMV data.

\section{The analysis suggests that the Colombian companies are overall in good}

financial health. The Colombian corporate sector is well capitalized, leverage is relatively low, and liquidity remains adequate. Profitability of the corporate sector has improved over the years, thanks mostly to efficiency gains. Analysis for a selected number of firms suggests that corporates in Colombia have low foreign exchange risk, although additional information on derivative positions could help provide a more complete assessment. EDF analysis supports the conclusions of the balance sheet analysis. Colombia has historically reported lower EDFs than the rest of the region; consequently, the implicit credit quality of Colombia's corporates compares well with others in the region.

4. The rest of the chapter is organized as follows. Section B describes some structural features of the corporate sector using two comprehensive datasets. ${ }^{2}$ Section $\mathrm{C}$ presents the balance sheet and profitability analysis. Section D discusses the foreign exchange exposure, and Section E presents analysis on EDFs, both for a selected number of corporates. Section $\mathrm{F}$ concludes the main body of the text, while two appendices address data issues.

\footnotetext{
${ }^{1}$ Prepared by Mercedes Vera Martin.

${ }^{2}$ See Appendix I for a brief description and comparison of the datasets.
} 


\section{B. Structural Features of the Corporate Sector in Colombia}

5. The Colombian corporate sector is highly segmented. First-tier companies have a significant market share and many of them are quoted in the Colombian stock exchange, with access to a more diversified pool of financing sources than smaller firms. The top 10 percent of corporates accounts for about 60 percent of the sector's assets, and 53 percent of liabilities. Smaller companies are generally non-exporters and are likely to depend more on bank lending or own resources for financing.

6. The corporate sector is dominated by companies in the service sector, which accounts for more than half of the total number of corporates (Table 1). Assets and liabilities are concentrated in manufacturing and services. The distribution of net profits differs, however, as "other sectors" (dominated by construction companies) represent about $1 / 4$ of total profits, despite accounting for only 10 percent of total sales. In all sectors, about 75 percent of the companies make profits, a ratio which has increased over time, except for agriculture. $^{3}$

\footnotetext{
${ }^{3}$ This follows the improvement in the companies' financing structure observed after the 1998 crisis. For more details, see Lima et al. (2006). See also Tenjo et al. (2006) for an analysis of the determinants of the capital structure of Colombian corporates during 1996-2002.
} 
Table 1. Colombia: Sectoral Characteristics of the Corporate Sector, 2002-07 (in percent of total, unless specified)

\begin{tabular}{|c|c|c|c|c|c|c|}
\hline & 2002 & 2003 & 2004 & 2005 & 2006 & 2007 \\
\hline \multicolumn{7}{|l|}{ Agriculture 1/ } \\
\hline Assets & 4 & 3 & 3 & 3 & 3 & 3 \\
\hline Liabilities & 4 & 3 & 3 & 3 & 3 & 3 \\
\hline Sales & 7 & 3 & 3 & 3 & 3 & 3 \\
\hline Net profits & 6 & 1 & 1 & 0 & 0 & 1 \\
\hline Number of companies (total) & 559 & 558 & 545 & 545 & 544 & 550 \\
\hline \multicolumn{2}{|l|}{ Manufacturing } & 74 & 68 & 66 & 70 & 69 \\
\hline Assets & 36 & 41 & 41 & 41 & 39 & 39 \\
\hline Liabilities & 42 & 42 & 42 & 42 & 41 & 41 \\
\hline Sales & 44 & 42 & 43 & 41 & 41 & 43 \\
\hline Net profits & 82 & 37 & 33 & 27 & 34 & 42 \\
\hline Number of companies (total) & 1,741 & 1,734 & 1,733 & 1,713 & 1,697 & 1,695 \\
\hline of which reporting positive net profits & 78 & 78 & 80 & 82 & 83 & 81 \\
\hline \multicolumn{7}{|l|}{ Services } \\
\hline Assets & 52 & 47 & 47 & 48 & 49 & 48 \\
\hline Liabilities & 44 & 46 & 44 & 43 & 43 & 43 \\
\hline Sales & 42 & 47 & 44 & 46 & 47 & 45 \\
\hline Net profits & -8 & 37 & 36 & 44 & 38 & 31 \\
\hline Number of companies (total) & 3,449 & 3,455 & 3,468 & 3,479 & 3,491 & 3,489 \\
\hline of which reporting positive net profits & 71 & 75 & 78 & 78 & 79 & 78 \\
\hline \multicolumn{7}{|l|}{ Other $2 /$} \\
\hline Assets & 8 & 9 & 9 & 9 & 9 & 10 \\
\hline Liabilities & 10 & 10 & 11 & 12 & 13 & 14 \\
\hline Sales & 7 & 8 & 10 & 10 & 10 & 10 \\
\hline Net profits & 20 & 25 & 31 & 29 & 27 & 25 \\
\hline Number of companies (total) & 627 & 629 & 630 & 639 & 644 & 642 \\
\hline of which reporting positive net profits & 66 & 70 & 71 & 75 & 76 & 77 \\
\hline
\end{tabular}

Source: BdR and author's calculation.

$1 /$ Includes fishing and forestry.

2/ Includes construction, eletricity, and mining. 


\section{Balance Sheet and Profitability Analysis}

7. This section focuses on the financial features of the Colombian corporate sector, both in terms of balance sheet structure and corporate performance. The analysis indicates that leverage is relatively low for the sector as a whole, and liquidity remains adequate. Further, the profitability of the corporate sector has improved over the years, thanks mostly to efficiency gains. Despite a period of strong economic growth and macroeconomic stability, the balance sheet structure and financial ratios have remained relatively stable.

\section{A Snapshot of the Corporate Sector in 2007}

8. Overall, the nonfinancial private sector is in good health, with assets more than double liabilities (Table 2). Based on the cross-sectional dataset, accounting capital (the difference between assets and liabilities) for the sector as a whole is estimated at 35 percent of GDP. Assets are predominantly long-term (64 percent of total assets), while liabilities remain mainly short-term (70 percent of total liabilities). Corporates that export and/or receive FDI report a better equity position, and FDI recipients are best capitalized. Three percent of the firms - representing 0.2 percent of total assets and 0.7 percent of total liabilities - are technically bankrupt (i.e., reporting negative accounting capital).

\section{Leverage, liquidity, and profitability seem adequate, with some differences} depending on export orientation. Exporters are more leveraged, with the debt-to-equity ratio double the level of non-exporters. All categories report similar debt maturity structures, with 70 percent of liabilities being short-term - a relatively high level. Liquidity seems adequate for the sector and across categories. Profitability indicators look also healthy, with aggregate gross margins of 29 percent and return on equity (RoE) of 8 percent, but does not compare well with the region (see next section). Non-exporters are less profitable.

\section{Sales and income are skewed toward exporters, especially toward those}

benefiting from FDI. Exporters are likely to be larger companies, on average, than those devoted to the domestic market. In light of their larger size, these firms may be benefiting from increasing returns to scale. Exporters, which represent 17 percent of the total number of corporates, account for about 55 percent of sales, and about half of net profits for the sector. Exporters that benefit from FDI are the most profitable. About 20 percent of total firms in the sample reported net losses in 2007-most of them are firms dedicated fully to the domestic market, and represent 13 percent of total assets, and about $9 \frac{1}{2}$ percent of total sales. Given the slowdown in economic growth projected for both Colombia and the world economy in 2009 , the number of companies with negative profits is likely to increase in the coming year. 
11. Stress testing suggests that the corporate sector is in a robust financial position. In order to assess the sensitivity of the corporate sector to potential adverse events, we consider a significant and negative shock to the value of assets and an increase in liabilities. A 20 percent decrease in the value of total assets would translate into 3,386 firms entering into technical default, although these firms are relatively small in size. They represent about 0.5 percent of GDP in accounting capital, and 6.5 percent of GDP in total liabilities. A 20 percent increase in liabilities would bring about 2,725 firms into technical default. Those represent about $1 / 4$ percent of GDP in terms of accounting capital and 5.5 percent of GDP in total liabilities. Given that the likelihood of such a shock is low, the results suggest the corporate sector could weather a large shock without posing significant systemic consequences.

Table 2. Colombia: Corporate Sector Financial Information, 2007

\begin{tabular}{lrrr}
\hline & Total & $\begin{array}{c}\text { Non- } \\
\text { exporters }\end{array}$ & Exporters \\
\hline Balance sheet (in percent of GDP) & & & \\
$\quad$ Total assets & 100 & 58 & 42 \\
$\quad$ Total liabilities & 36 & 18 & 19 \\
$\quad$ Current liabilities & 25 & 12 & 13 \\
$\quad$ Long-term liabilities & 11 & 5 & 5 \\
$\quad$ Accounting capital & 63 & 40 & 23 \\
Financial ratios & & & \\
$\quad$ Leverage and debt structure & & & \\
$\quad$ Debt to equity 1/ & 0.6 & 0.4 & 0.8 \\
$\quad$ Short-term debt to total debt & 0.7 & 0.7 & 0.7 \\
$\quad$ Liquidity indicators & & & \\
$\quad$ Quick ratio ( in percent) 2/ & 97.6 & 99.2 & 96.1 \\
$\quad$ Current ratio 3/ & 1.4 & 1.4 & 1.4 \\
Profitability indicators & & & \\
$\quad$ Gross margins (in percent) 4/ & 29.2 & 30.1 & 28.5 \\
$\quad$ Net margins (in percent) 5/ & 6.5 & 7.1 & 6.1 \\
$\quad$ Return on equity (annual) 6/ & 7.9 & 6.0 & 11.3 \\
Income statement (in percent of GDP) & & & \\
Sales & 77.2 & 34.1 & 43.1 \\
Gross profit & 22.6 & 10.3 & 12.3 \\
Operating earning & 7.3 & 3.1 & 4.2 \\
Net profit & 5.0 & 2.4 & 2.6 \\
\hline
\end{tabular}

Sources: BdR and author's calculations.

1/ Debt is the sum of current and long-term liabilities. The equity measure used here is accounting capital, a book value concept

2/ Current assets minus inventories to current liabilities.

$3 /$ Current assets to current liabilities.

$5 /$ Operating earning (EBIT) in percent of sales.

$5 /$ Net profit in percent of sales.

6/ Net profit in percent of accounting capital. 


\section{The Performance of the Corporate Sector during 2002-07}

12. Over time, the balance sheet of the aggregate corporate sector has shrunk significantly (Table 3). Time-series data indicate that the consolidation occurred mainly in 2003-04. Assets have shrunk by 25 percent of GDP, and liabilities by 10 percent of GDP between 2002 and 2007. Corporates, however, have remained well-capitalized, with capital of 48 percent of GDP in 2007.

13. Despite improved economic conditions and high economic growth, leverage ratios have improved little, while liquidity has remained stable. Compared to the crosssectional dataset, the firms in the sample are marginally less leveraged, with a debt-to-equity ratio of 0.5 . Despite some improved leverage over time and strengthening of economic fundamentals, the reliance on short-term liabilities has remained stable, at 70 percent of total liabilities. Further study is needed to assess the reasons why there is such high reliance on short-term liabilities, given the greater vulnerabilities associated with short-run funding.

14. Profitability has improved over time. Gross margins have remained relatively stable, but returns on assets and on equity have improved as corporates have reduced assets and equity over time. Profitability has also improved as a result of the streamlining of costs.

\section{Large firms are in a marginally better financial condition than the corporate} sector overall. Large firms merit separate examination, given the systemic implications of their operations. The data reveal that the top 10 percent of corporates (according to asset size, about 675 firms in 2007) account for about 80 percent of total assets, and about 80 percent of capital. The leverage structure of large firms is in line with that of the cross-sectional sample. These firms also have maturity structure for liabilities. Liquidity remains at levels comparable to the sector as a whole. Large firms, which are more likely to be exporters and receive FDI, are more profitable. While capturing 64 percent of total sales, they account for about 80 percent of total net profits.

16. From a regional perspective, Colombian corporates have relatively low levels of leverage, but report weaker liquidity and profitability indicators (Table A2). The crosscountry analysis is based on a reduced sample of corporates (between 640 to 750 firms, and 20 large firms for Colombia) in light of data availability constraints. Keeping this caveat in mind, the data suggest that over time, leverage indicators have improved, especially in terms of the maturity structure of debt. Despite efficiency gains reported for the previous analysis for a larger sample, profitability is well below the regional average. 
Table 3. Colombia: Corporate Sector Financial Information, 2002-07

\begin{tabular}{|c|c|c|c|c|c|c|}
\hline & 2002 & 2003 & 2004 & 2005 & 2006 & 2007 \\
\hline \multicolumn{7}{|l|}{ Balance sheet (in percent of GDP) } \\
\hline Total assets & 102 & 81 & 76 & 77 & 77 & 75 \\
\hline Total liabilities & 37 & 33 & 29 & 27 & 27 & 27 \\
\hline Current liabilities & 22 & 21 & 19 & 18 & 19 & 18 \\
\hline Long-term liabilities & 14 & 11 & 9 & 8 & 8 & 8 \\
\hline Accounting capital & 65 & 48 & 47 & 51 & 50 & 48 \\
\hline \multicolumn{7}{|l|}{ Financial Ratios } \\
\hline \multicolumn{7}{|l|}{ Leverage and debt structure } \\
\hline Debt to equity $1 /$ & 0.6 & 0.7 & 0.6 & 0.5 & 0.5 & 0.5 \\
\hline Short-term debt to total debt & 0.6 & 0.6 & 0.7 & 0.7 & 0.7 & 0.7 \\
\hline \multicolumn{7}{|l|}{ Liquidity Indicators } \\
\hline Quick ratio 2/ & 92.6 & 91.9 & 97.3 & 97.9 & 94.0 & 98.0 \\
\hline Current ratio $3 /$ & 1.3 & 1.3 & 1.4 & 1.4 & 1.4 & 1.4 \\
\hline \multicolumn{7}{|l|}{ Profitability Indicators } \\
\hline Gross margins (in percent) 4/ & 29.1 & 29.2 & 28.8 & 29.0 & 28.9 & 29.8 \\
\hline Net margin (in percent) $5 /$ & 2.6 & 4.6 & 5.5 & 6.9 & 6.6 & 6.9 \\
\hline Return on equity (annual) 6/ & 2.5 & 5.9 & 6.3 & 7.5 & 7.6 & 8.2 \\
\hline \multicolumn{7}{|c|}{ Income statement (in percent of GDP) } \\
\hline Sales & 63.4 & 62.2 & 55.1 & 55.2 & 57.4 & 57.2 \\
\hline Gross profit & 18.4 & 18.1 & 15.9 & 16.0 & 16.6 & 17.0 \\
\hline Operating earning & 4.7 & 4.4 & 4.9 & 5.2 & 5.8 & 5.8 \\
\hline Net profit & 1.6 & 2.8 & 3.0 & 3.8 & 3.8 & 3.9 \\
\hline
\end{tabular}

Sources: BdR and author's calculations

$1 /$ Debt is the sum of current and long-term liabilities. The equity measure used here is accounting capital, which is a book value concept.

2/ Current assets minus inventories to current liabilities

3/ Current assets to current liabilities.

4/ Gross profit in percent of sales.

$5 /$ Net profit in percent of sales.

6/ Net profit in percent of accounting capital.

\section{Assessing the Foreign Exchange Exposure of the Corporate Sector}

\section{This section analyzes the exposure of a selected number of corporates to}

exchange rate movements. Given the high volatility of the peso compared to other

currencies in the region, an assessment of the effects of changes in the peso on the financial situation of corporates is of great interest. The analysis in this section uses data for 78 firms in $2007,{ }^{4}$ with aggregate assets and liabilities accounting for about a fifth of the crosssectional sample. Foreign-exchange assets and liabilities represent a low share of total assets and liabilities. Foreign exchange assets are small (less than 1 percent of total assets). The share of total foreign-currency debt is low on average, about 7 percent, and half of the firms hold no foreign currency denominated liabilities. With respect to long-term liabilities, about 22 percent were denominated in foreign exchange; for short-term liabilities, the corresponding figure was 12 percent. The low level of foreign exchange liabilities could be a reflection of balance-sheet restructuring after the 1998 crisis and the resulting losses for firms with high levels of foreign currency debt. It could also be the consequence of firms' limited

\footnotetext{
${ }^{4}$ For details on the data, see Kamil (2008).
} 
access to foreign financing, or the preference of firms to finance investment with FDI or the wide availability of domestic credit in recent years. ${ }^{5}$

18. The foreign exchange rate exposure of the corporate sector is low. The aggregate foreign exchange exposure - measured by the difference between foreign exchange assets and liabilities - of these firms was a positive US\$2 billion at end-2007 (61/4 percent of capital). However, the aggregate data understates exposure as long-term foreign exchange exposure should not be netted out from the short-term exposure of other firms. In the sample, 24 firms reported positive foreign exchange exposure. Among the firms with negative foreign-exchange exposure, the median position of the top 10 firms amounts to 17 percent of capital, while for the first quartile it is 24 percent of capital. The top ten exporters (with exports accounting, on average, for about 60 percent of their sales) report a better position, as they benefit from their "natural hedge" as exporters. ${ }^{6}$ For these firms, foreign exchange exposure equals $4 \frac{1}{2}$ percent of capital. Four non-exporters report a net foreign exposure above 10 percent of capital.

\section{Stress testing reveals that the corporate sector is resilient to a change in the} value of the peso. A significant depreciation of the peso (of 50 percent) would only bring one company in the sample under technical default. This is mainly because of the limited foreign exchange exposure, as well as the fact that these firms are well capitalized, and their "domestic position" (the difference between domestic assets and liabilities) is quite strong.

\section{Additional information on derivative positions could help provide a broader} assessment of potential exchange rate risks. The balance sheet data do not incorporate information on firms' foreign exchange derivative positions. An additional challenge-faced by the Colombian authorities and other emerging markets - is how to assess information on risks related to off-shore derivative positions. Nevertheless, incorporating this information into the analysis would be helpful in providing a more comprehensive picture of potential risks.

\section{E. Market-Based Assessments of Selected Corporates in Colombia}

\section{This section uses contingent claims analysis (CCA) to assess risks in a selected} number of Colombian corporates. ${ }^{7}$ The CCA approach is based on the estimation of the default probability by an entity on its obligations, and is used to assess creditworthiness in the corporate sector. The analysis here uses Moody's-KMV estimates of expected default

\footnotetext{
${ }^{5}$ For example, a limited number of corporates hold credit ratings provided by internationally-known credit ratings, which may hamper access to international capital markets.

${ }^{6}$ For a cross-country analysis on the foreign currency exposure of the corporate sector oaver time, see IMF (2008). The study shows that foreign-currency liabilities have fallen over time, both as a fraction of total liabilities and as a fraction of exports.

${ }^{7}$ For a description of the methodology, see Chapter 1.
} 
frequencies (EDFs) for Colombian and other Latin American corporates, which are constructed with market-based data. While the balance sheet and income statement analysis provides a good sense of the health of the corporate sector, it is based on historical data. The CCA approach, in contrast, is based on market data, which presumably incorporates a forward-looking, collective view of risk by market participants. Such a forward-looking element cannot be captured by traditional balance sheet measures.

\section{Colombia has historically reported lower EDFs than the rest of the region}

(Figure 1). Estimated EDFs for Colombian firms have been relatively stable since 2003 (the earliest year for which data are available), and the average median EDF is estimated at 0.15 percent. $^{8}$ The corporate sectors of both Colombia and other Latin American countries have benefited from the positive environment from 2003 to end-2007, as equity market and credit conditions eased significantly, thanks to buoyant liquidity. The estimated average EDF for the region was 0.40 percent, but there was a sharp decrease in EDFs during 2003-mid 2006.

Figure 1: Expected Default Frequencies, 2003-08

(in percent)

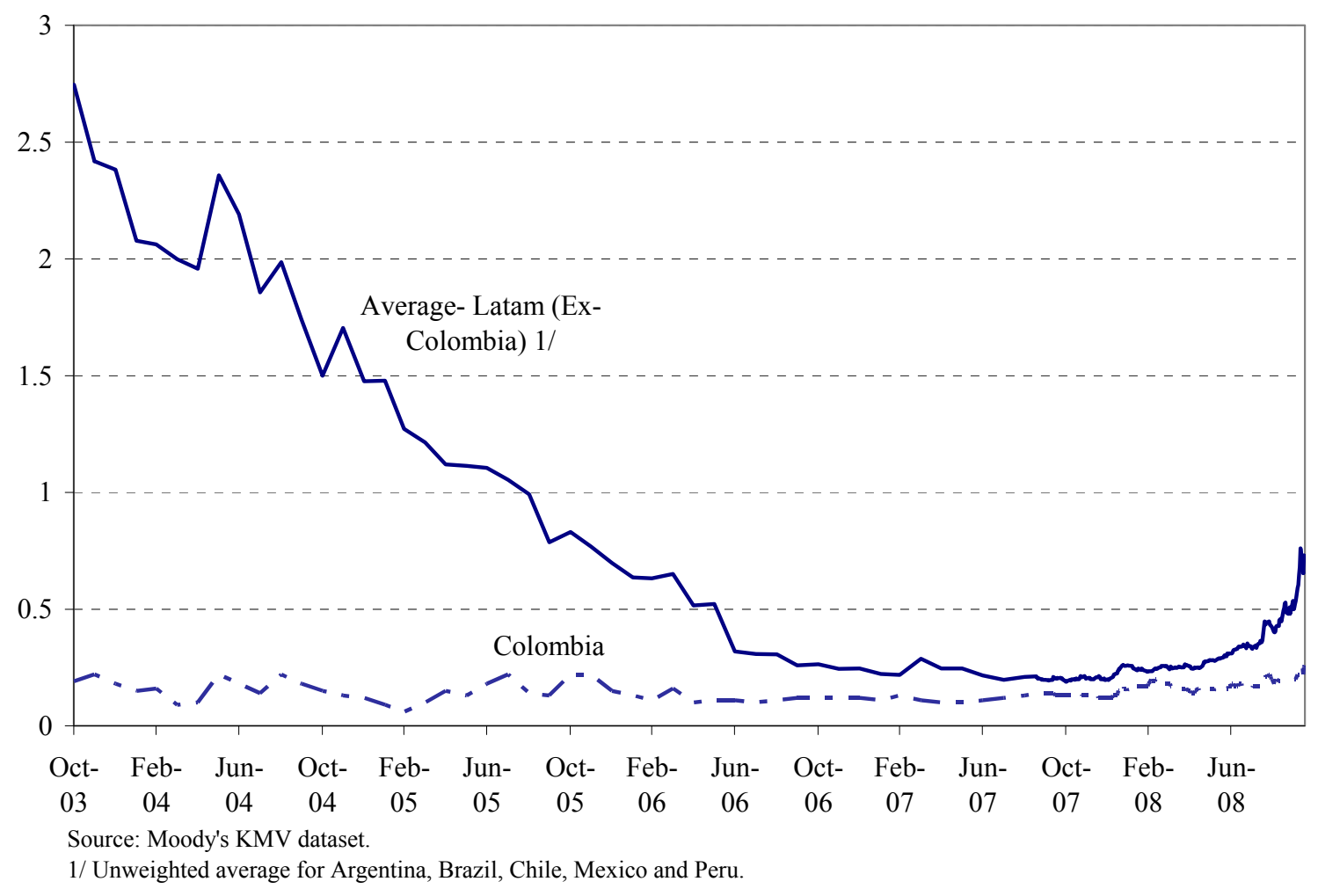

\footnotetext{
${ }^{8}$ Data for the region includes 670 corporates. For Colombia, the sample includes 20 corporates representing 8 percent of total assets and 5 percent of total liabilities in 2007 . For an analysis of the determinants of default probabilities for Colombian corporates during the period 1998-2005, see Zamudio (2007).
} 
23. Through the current financial turbulence, corporate sectors throughout Latin America have been negatively affected, as reflected by increasing EDFs. The average EDF for Colombia is 2.65 percent, well below the average for the region ( 5.55 percent). Corporates in the region have been affected by increasing default frequencies for both highrisk and low-risk firms (Figure 2). EDFs have increased most sharply in Colombia for the highest risk firms (those in the top 75 percent of the distribution of EDFs), in line with the region. Across sectors, construction and services companies have been most affected, with significant increases in EDFs since September 2008.

24. In line with lower EDFs, the implicit credit quality of Colombia's corporates compares well with other corporates in Latin America. Tables 4 and 5 provide details on the distribution of EDFs and the implicit credit rating for Colombia and Latin America as a whole. The reported implicit credit rating for the median Colombian firm is Ba1, while the average for the Latin American region is Ba2. 50 percent of the Colombian companies report EDFs consistent with investment grade status. 
Figure 2. Colombia: EDFs for Selected Corporates, 2008

(in percent)
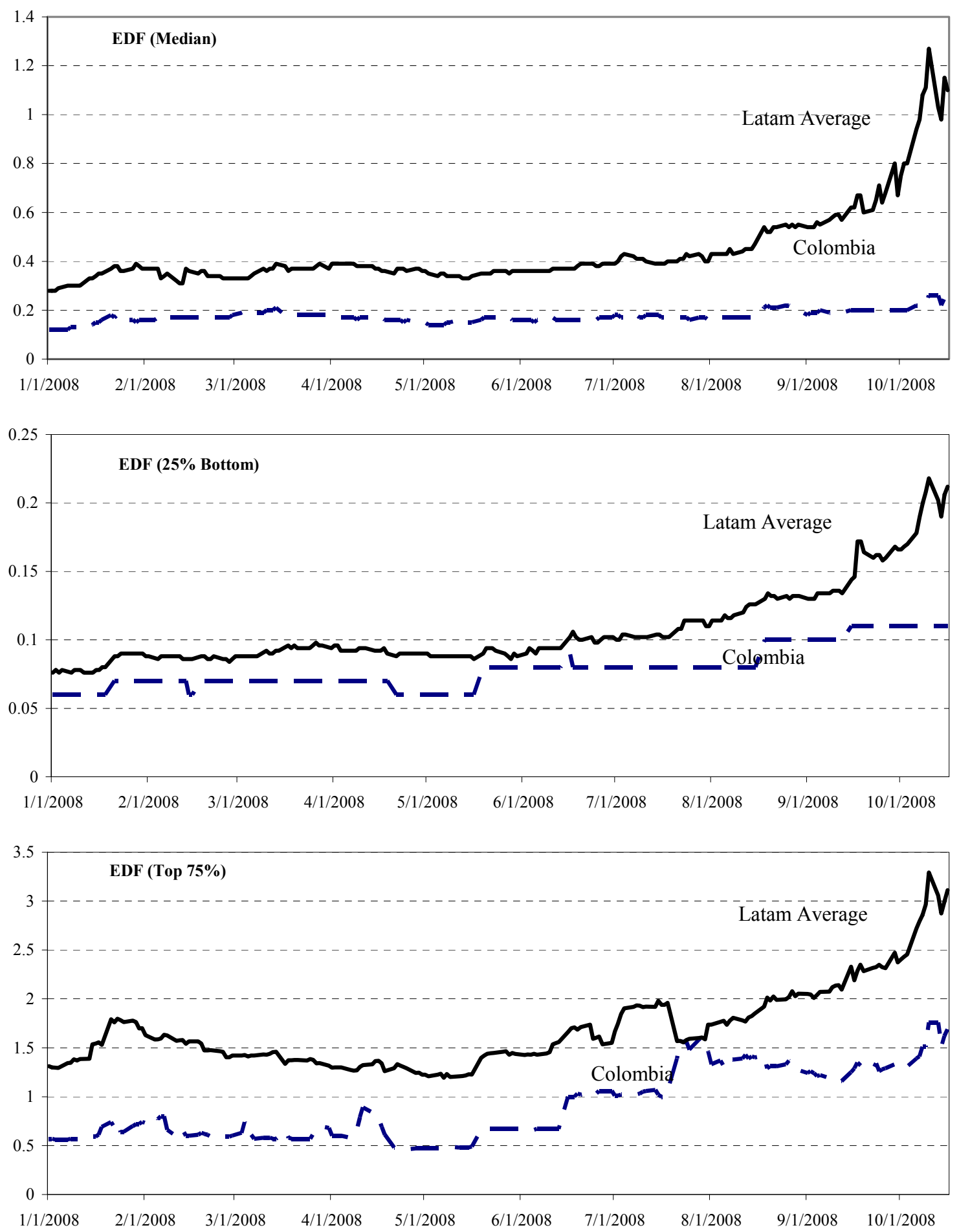

Source: Moody's KMV Model.

1/ Unweighted average of corporate sector's estimated EDF for Argentina, Brazil, Chile, Mexico and Peru. 


\begin{tabular}{|c|c|c|}
\hline & Latin America & Colombia \\
\hline Caa-C & 101 & 1 \\
\hline $\mathrm{B}$ & 143 & 4 \\
\hline $\mathrm{Ba}$ & 168 & 5 \\
\hline Baa & 120 & 5 \\
\hline A & 78 & 3 \\
\hline Aaa-Aa & 60 & 2 \\
\hline
\end{tabular}

Table 5. Colombia: EDF Distribution by Credit Quality 1/

\begin{tabular}{lclcl}
\hline & \multicolumn{3}{c}{ Colombia } & \multicolumn{2}{c}{ Latin America } \\
\cline { 2 - 5 } & & Credit & Credit \\
Distribution & EDF & Rating & EDF & Rating \\
\hline Minimum & $0.01 \%$ & Aa1 & $0.01 \%$ & Aaa \\
First quartile & $0.10 \%$ & A3 & $0.23 \%$ & Baa1 \\
Median & $0.38 \%$ & Ba1 & $1.12 \%$ & Ba2 \\
Third quartile & $1.66 \%$ & B1 & $5.50 \%$ & B2 \\
Maximum & $35.00 \%$ & C & $35 \%$ & C \\
\hline
\end{tabular}

\section{F. Conclusions}

\section{The Colombian corporate sector is in good health.}

Balance sheet analysis suggests that the Colombian corporate sector is well capitalized, leverage is relatively low, and liquidity remains adequate. Further, the profitability of the corporate sector has improved over the years, thanks mostly to efficiency gains.

However, despite a period of strong economic growth and macroeconomic stability, the balance sheet structure and financial ratios have remained relatively stable, with high reliance on short-term liabilities.

$>$ Analysis for a selected number of firms suggest that corporates in Colombia face low foreign-exchange risk, and that the corporate sector is robust to large shocks, including from the external sector. Additional information on derivative positions could help provide a broader assessment of potential exchange rate risks.

$>$ Market-based measures of risk confirm the conclusions from the balance sheet analysis. Colombia has historically reported lower EDFs than the rest of the region; and although corporate sectors in Latin America have been negatively affected through the current financial turbulence, a modest share of Colombian corporates have been affected. In line with lower EDFs, the implicit credit quality of Colombia's corporates compares well with the region.

\section{Further work could be undertaken on identifying the determinants of EDFs.}

Once these factors are identified, they could potentially serve as early warning indicators and thus help anticipate changes in the financial condition of the corporate sector. This, in turn, could be helpful for assessing the macroeconomic risks associated with changes in corporate sector health. 


\section{Appendix I: Description of the Datasets}

In order to get a comprehensive view of the corporate sector, the analysis uses two datasets, which are collected by Superintendency of Corporations (the supervisory body for the corporate sector), and processed by the Banco de la República (BdR).

The first dataset contains a cross-sectional information on balance sheet and income statements for about 21,200 firms for 2007. The data identifies corporates that are exporting as well as those that are benefiting from foreign direct investment (FDI). Of the total of companies included in the dataset, 3,544 are exporters, 2,712 benefit from FDI, and about 950 corporates are both exporters and benefit from FDI. The analysis provides a snapshot of the state of the corporate sector in 2007, and allows for an assessment of whether exporters and/or FDI recipients are in a better financial position than other corporates.

The second dataset provides a time-series perspective for the period 2002-07. This allows an assessment of the evolution of the balance sheet and income accounts of Colombian corporates during the most recent economic expansion. While the dataset is less comprehensive in terms of the number of firms included (about 6,400 companies), it captures about $3 / 4$ of balance sheet and income accounts of the corporate sector in 2007 (Table A1).

Table A1. Colombia: Features of Corporate Sector Data

\begin{tabular}{|c|c|c|c|}
\hline & $\begin{array}{c}\begin{array}{c}\text { Cross-sectional } \\
\text { dataset } \\
2007\end{array} \\
(1) \\
\text { (in percent }\end{array}$ & $\begin{array}{c}\begin{array}{c}\text { Time-series } \\
\text { dataset } \\
2002-07\end{array} \\
(2) \\
\text { GDP })\end{array}$ & $\begin{array}{c}\begin{array}{c}\text { Comparing } \\
\text { datasets in } \\
2007\end{array} \\
(3)=(2) /(1) \\
\text { (in percent) }\end{array}$ \\
\hline \multicolumn{4}{|l|}{ Balance sheet structure } \\
\hline Total assets & 99.6 & 75.1 & 75 \\
\hline Current assets & 35.1 & 25.3 & 72 \\
\hline Non-current assets & 64.5 & 49.7 & 77 \\
\hline Total liabilities & 36.1 & 25.7 & 71 \\
\hline Current liabilities & 25.3 & 18.1 & 71 \\
\hline Non-current liabilities & 10.8 & 7.6 & 71 \\
\hline Accounting capital & 63.5 & 49.4 & 78 \\
\hline \multicolumn{4}{|c|}{ Income Statement Information } \\
\hline Gross earning & 22.6 & 17.0 & 75 \\
\hline Administrative costs & 7.0 & 4.7 & 67 \\
\hline Sale operational costs & 8.2 & 6.5 & 79 \\
\hline Operational earning & 7.3 & 5.8 & 79 \\
\hline Non-operational income & 6.1 & 4.7 & 77 \\
\hline Non-operational costs & 6.5 & 5.0 & 78 \\
\hline Earning before taxes & 6.9 & 5.4 & 79 \\
\hline Net income & 5.0 & 3.9 & 78 \\
\hline Number of firms & 21,210 & 6,375 & 30 \\
\hline
\end{tabular}

Source: BdR. 


\section{Appendix II: Comparative Data on Financial Sector Indicators in Latin America}

The cross-country analysis is based in a limited number of corporates, of about 640-750 firms for the region and about 20 for Colombia, depending on the indicator. Although this analysis is insufficient to draw conclusions about the Colombian corporate sector at large, it provides some indication of the main financial vulnerabilities, as the set of companies is likely to be close to the universe of firms with access to foreign capital and the local capital markets.

All indicators in Table A2 refer to market capitalization-weighted averages. These weighted averages have two advantages. First, they collapse the data toward the largest, economically most important firms, thereby focusing on systemic corporate risk. Second, they control for differences across countries in depth of coverage.

Table A2. Average Financial Ratios for Corporate Sectors in Latin America, 2002-07

\begin{tabular}{|c|c|c|c|c|c|c|}
\hline & 2002 & 2003 & 2004 & 2005 & 2006 & 2007 \\
\hline \multicolumn{7}{|l|}{ Leverage Indicators } \\
\hline \multicolumn{7}{|l|}{ Debt to equity (in percent) } \\
\hline Colombia & 89.3 & 81.6 & 64.2 & 60.2 & 57.6 & 75.5 \\
\hline Emerging America 1/ & 160.9 & 114.7 & 116.6 & 104.6 & 108.8 & 115.0 \\
\hline \multicolumn{7}{|c|}{ Short-term debt to total debt (in percent) } \\
\hline Colombia & 49.4 & 50.5 & 57.9 & 42.8 & 41.3 & 38.4 \\
\hline Emerging America & 45.4 & 45.4 & 46.2 & 51.2 & 50.7 & 48.1 \\
\hline \multicolumn{7}{|l|}{ Liquidity Indicators } \\
\hline \multicolumn{7}{|l|}{ Current Ratio } \\
\hline Colombia & 1.6 & 1.7 & 1.8 & 1.6 & 1.1 & 1.2 \\
\hline Emerging America & 1.5 & 1.7 & 1.7 & 1.3 & 1.6 & 1.6 \\
\hline \multicolumn{7}{|l|}{ Quick Ratio } \\
\hline Colombia & 1.1 & 1.2 & 1.2 & 1.0 & 0.7 & 0.9 \\
\hline Emerging America & 1.1 & 1.2 & 1.2 & 1.0 & 1.2 & 1.1 \\
\hline \multicolumn{7}{|l|}{ Profitability Indicators } \\
\hline \multicolumn{7}{|c|}{ Return on equity (in percent) } \\
\hline Colombia & 9.7 & 9.8 & 10.0 & 8.9 & 7.6 & 10.5 \\
\hline Emerging America & 5.4 & 16.7 & 19.2 & 12.6 & 17.6 & 23.7 \\
\hline \multicolumn{7}{|c|}{ Return on assets (in percent) } \\
\hline Colombia & 5.4 & 5.2 & 4.3 & 3.8 & 3.5 & 4.6 \\
\hline Emerging America & 7.7 & 8.6 & 9.7 & 7.5 & 9.5 & 10.2 \\
\hline
\end{tabular}

Source: Worldscope.

1/ Emerging America includes Argentina, Brazil, Chile, Colombia, Mexico, Peru and Venezuela. 


\section{References}

Kamil, Herman, 2008, “A New Database on the Currency and Maturity Composition of Firms' Balance Sheets in Latin America: 1992-2007," Unpublished, Washington: International Monetary Fund.

Lima, J.M.; Montes, E; Varela, C; and Wiegand, J., 2006, "Sectoral Balance Sheet Mismatches and Macroeconomic Vulnerabilities in Colombia, 1996-2003," International Monetary Fund, WP/06/5.

International Monetary Fund, 2008, Regional Economic Outlook: Western Hemisphere, October.

Tenjo, F.; López, E; and Zamudio, N., 2006, “Determinantes de la Estructura de Capital de las Empresas Colombianas (1996-2002)," Borradores de Economia No. 380, Banco de la República, Bogota.

Zamudio, N., 2007, "Determinantes de la Probabilidad de Incumplimiento de las Empresas Colombianas," Borradores de Economia No. 466, Banco de la República, Bogota. 


\section{Policy Options for DeAling With EXTERnAl ShOCKS: InSights FROM The GIMF FOR COLOMBIA ${ }^{1}$}

\section{A. Introduction}

1. What policy options work best in addressing external shocks? Turbulence in financial markets and uncertainty about the outlook for global growth have all increased the importance of understanding the macroeconomic effects of external shocks and how best to respond to them. This is no less important in Colombia than other emerging market countries, as external shocks have historically contributed to a large share of the variance of output (Abrego and Osterholm, 2008).

2. The Colombian authorities now face the challenge of guiding the economy toward a soft landing in the face of a harsher global environment. Economic growth is projected to slow to from over 7 percent in 2007 to about 31/2 percent in 2008 as a result of less buoyant domestic demand conditions and, more recently, the effects of global shocks. For 2009, growth is projected to ease further. At the same time, inflation - at almost 8 percent $(\mathrm{y} / \mathrm{y})$ for some months in the third quarter of 2008 - has been running well above the Banco de la República (BdR)'s targets for inflation. As such, the authorities face a difficult macroeconomic landscape in which they attempt to both reduce inflation toward their medium-term target while preventing an excessively sharp decline in growth in the context of an unfavorable global outlook.

3. The tightening of financial conditions in the wake of global financing turbulence also presents a challenge for macroeconomic stabilization. As in other emerging market countries, equities, sovereign spreads, and exchange rates have been adversely affected since the turbulence of mid-September 2008. In addition, long-term interest rates have risen in light of increased global risk aversion. In this context, the scope for accommodative fiscal policy - for example, through the operation of automatic stabilizers - is unclear. This is particularly the case in Colombia, where the 2009 fiscal stance already entails a mild fiscal expansion of about $1 / 2$ percentage point of GDP.

4. While the role of monetary policy in responding to shocks has been extensively studied, relatively little work has been done to empirically assess the role of fiscal policy. A number of central banks have developed large scale models to predict the effects of monetary policy, and these models can be used to assess the effects of monetary policy in response to external shocks. However, as discussed in several recent papers, these models often cannot adequately replicate the dynamic effects of fiscal policy found in the empirical

\footnotetext{
${ }^{1}$ Prepared by Benedict Clements, Enrique Flores, and Daniel Leigh.
} 
literature. ${ }^{2}$ Conventional models used for monetary policy typically feature agents with infinite planning horizons, and predict that fiscal policy is ineffective in influencing aggregate demand and external current account balances. As such, these models are inadequate for assessing the role of different fiscal policy interventions in the face of changes in the external environment.

\section{This paper utilizes an open-economy structural model to assess the impact of} different external shocks on Colombia and alternative monetary and fiscal policy responses. The analysis builds on the Global Integrated Monetary and Fiscal (GIMF) model developed at the IMF (see Kumhof and Laxton, 2007a) and the Colombia-specific version presented in Leigh (2008). GIMF reflects the latest advances in new open-economy macroeconomic theory, and embodies a number of nominal and real rigidities that permit it to make empirically plausible predictions regarding the dynamic effects of fiscal and monetary policy. The model is used to assess to effects of shocks to world income, an exogenous trade shock, and an increase in global risk aversion on key macroeconomic variables, as well as the effect of differing policy responses.

6. The paper also addresses the effects of fiscal policy under differing assumptions regarding financing conditions. When financing conditions are normal, a country with a relatively low level of public debt to GDP, a credible fiscal policy framework, and low financing needs, may be able to allow automatic stabilizers to function to help soften the output effects of external shocks. However, under less favorable financing conditions - when higher deficits trigger a substantial increase in risk premia - this may not be the case.

7. The remainder of the paper is structured as follows. Section B presents the key features of the model. Sections $\mathrm{C}$ and D report the results, and Section E concludes with a summary of policy implications.

\section{B. The Model}

8. GIMF is a dynamic general equilibrium model developed at the Fund that is equipped for both monetary and fiscal policy analysis. ${ }^{3}$ The model's multiple nonRicardian features, nominal and real rigidities, monetary policy reaction function, and fiscal policy reaction function yield plausible macroeconomic responses to changes in fiscal and monetary policy.

\footnotetext{
2 See, for example, Kumhof and Laxton (2007). Examples of large-scale models used for monetary policy analysis include the Banco de la República's Model of Transmission Mechanisms (MMT), the IMF's FPAS and GEM, the Federal Reserve's SIGMA, and the ECB's NAWM.

${ }^{3}$ This section draws on Leigh (2008).
} 


\section{Ricardian equivalence is assumed not to hold for four reasons:}

- Overlapping generations. The model features overlapping generation agents (OLG) with finite lifetimes. These agents are myopic in the sense that they perceive debt-financed tax cuts as an increase in their human wealth, and attach a low probability to having to pay for them in the future.

- $\quad$ Life-cycle labor productivity. Workers have a life-cycle labor productivity pattern that implies a declining rate of productivity as workers age. This feature means that workers discount the effects of future payroll tax increases as the latter are likely to occur when they are older and less productive.

- $\quad$ Liquidity-constrained consumers. The model contains liquidity-constrained consumers (LIQ) who do not have access to financial markets to smooth consumption, and change their consumption one-for-one with changes in after-tax income. $^{4}$

- Distortionary taxes. The model includes payroll and capital income taxes that are distortionary because labor effort and private investment respond to relative price movements that result directly from variations in tax rates.

10. Monetary policy is effective due to nominal and real rigidities. The model features include nominal rigidities like a Phillips curve for each sector, wage rigidities, and price to market; as well as real rigidities with respect to consumption habits, and adjustment costs for changes in investment, imports, and retail sales.

11. Monetary and fiscal policy are modeled through reaction functions, including an inflation forecast-based rule (IFB), and a simple fiscal policy rule:

- The central bank targets inflation by adjusting the nominal interest rate following a standard inflation forecast-based (IFB) rule (see Leigh, 2008, for additional details). The specification of this monetary policy rule is consistent with the IFB rule embodied in the BdR's MMT, as described by Gómez, Uribe, and Vargas (2002), and López (2003).

- $\quad$ The government determines how the fiscal balance-to-GDP ratio responds to excess tax revenue using a simple fiscal policy rule:

\footnotetext{
${ }^{4}$ These consumers solve an intra-temporal optimization problem for choosing consumption and leisure levels. However, without access to financial markets, they cannot smooth consumption in response to temporary changes in disposable income.
} 


$$
\frac{f b a l_{t}}{g d p_{t}}=\phi^{*}+d\left(\frac{\tau_{t}-\tau_{t}^{*}}{g d p_{t}}\right)
$$

where $\frac{f b a l_{t}}{g d p_{t}}$ is the fiscal balance-to-GDP ratio.

If the response parameter $d=0$, the fiscal balance is kept equal to $\phi^{*}$ at all times. For example, if $d=0$ and the economy experiences an upswing with actual tax revenue $\tau_{t}$ exceeding steady-state tax revenue $\tau^{*}{ }_{t}$, the fiscal balance remains unchanged, and the excess tax revenue is spent. Such a response corresponds to a "balanced budget" rule and is here defined as procyclical. A response of $d<0$ would also qualify as procyclical. As the response parameter $d$ increases in the positive range, a greater share of the excess tax revenue is saved. When $d=1$, a 1 percentage point of GDP increase in excess tax revenue translates into a 1 percentage point increase in the fiscal balance, a response consistent with a "structural balance" rule where automatic stabilizers are allowed to operate. ${ }^{5}$

\section{Since financing conditions play a key role in determining the capacity to pursue} counter-cyclical fiscal policies, the model incorporates a country-specific risk premia. Domestic interest rates incorporate a country specific risk premia denoted $\rho_{t}$, which enters the model via a risk-adjusted uncovered interest parity (UIP) equation for foreign currency bonds: ${ }^{6}$

$$
i_{t}=i_{t}^{R W} E_{t} \varepsilon_{t+1}\left(1+\rho_{t}\right)
$$

where $i_{t}^{R W}$ is the gross nominal interest rate in the rest of the world, and $\varepsilon_{t+1}$ denotes future gross nominal exchange rate depreciation. ${ }^{7}$ The domestic risk premium $\rho_{t}$ is assumed to have the following non-linear form:

$$
\rho_{t}=\delta_{1}+\frac{\delta_{2}}{\left((d e b t / g d p)^{\max }-\left(d e b t_{t} / g d p_{t}\right)\right)^{\delta_{3}}}
$$

\section{Domestic interest rates are thus a function not only of the level of public debt to} GDP, but also an exogenous risk premia factor, $\delta_{1}$. Given that recent increases in interest

\footnotetext{
${ }^{5}$ The rule is implemented by modifying tax rates to achieve the desired objective.

${ }^{6}$ There are two financial assets in the model, private bonds that are traded internationally, and government bonds that are subject to complete domestic bias.

${ }^{7}$ If the risk premium $\rho_{t}=0$, an expected depreciation of the domestic currency by 1 percent is, via arbitrage, associated with an increase in the domestic interest rate by about 1 percentage point above the rest-of-the-world interest rate.
} 
rates for emerging market debt have little to do with concerns about debt levels per se - but rather changes in global risk aversion and more generalized concerns regarding financing conditions in emerging market countries - the relationship between fiscal policy and financing conditions may best be simulated by shifts in the parameter $\delta_{1} \cdot{ }^{8}$

\section{Macroeconomic Effects of External Shocks and Alternative Policy Responses}

\section{This section reports on the results of three scenarios under which the external} environment deteriorates. In each case, the results are reported in terms of the deviation from the baseline, i.e., the steady state that would occur if the shock did not occur. In the first scenario, there is an exogenous shock to trade exports of about 10 percent. In the second scenario, global growth falls by some 2 percentage points. In scenario three, global financial market turbulence is assumed to lead to an increase in risk premia for public debt of about 100 basis points.

\section{For each of the shocks, the effect on macroeconomic variables of different policy} responses is also assessed. In particular, three policy responses are considered: (i) a baseline case in which monetary policy responses rapidly in light of the expected effect of the shock on inflation, as is the case under Colombia's inflation targeting regime; under this scenario, fiscal policy is assumed to follow a constant deficit rule, that is $\mathrm{d}=0$; (ii) a delayed response, whereby monetary policy remains unchanged for a period of time with fiscal policy as in the baseline; ${ }^{9}$ and (iii) a cyclically neutral fiscal stance $(\mathrm{d}=1)$, under which the budget deficit is allowed to increase in response to the adverse effect of the shock on growth and tax revenues; under this scenario, the monetary policy reaction function is the same as under the baseline. For all shocks, the model results show the impact on macroeconomic variables over a period of 32 quarters.

16. Under the assumption of favorable financing conditions, the government can run a cyclically neutral fiscal policy without strong adverse effects on interest rates. The model is calibrated as in Leigh (2008), where running temporary deficits - as in the case when automatic stabilizers are allowed to work - has a minor impact on interest rates. Under this scenario, an accommodative fiscal policy can help reduce the output costs of external shocks. Simulations with more adverse financing conditions-which have an important bearing on the results - are presented in section D.

17. The exchange rate is assumed to be fully flexible. The monetary policy reaction is not a function of the exchange rate, so exchange rate flexibility plays an important role in

\footnotetext{
${ }^{8}$ Another option would be recalibrate the model and assume a more adverse relationship between the debt to GDP ratio and interest rates. However, given that the change in the deficit may trigger changes in expectations in a non-continuous fashion, we simulated this with an upward shift in the exogenous component of the interest rate equation.

${ }^{9}$ The delayed response is simulated by mechanically increasing the inertia of monetary policy for the two quarters following the shock.
} 
helping the economy adjust to these shocks, and helps minimize their adverse effect on output and the external accounts.

\section{Case 1: exogenous reduction in trade}

\section{Under this scenario, the shock is simulated as an exogenous decline in}

Colombian exports. This is modeled as an increase in the home bias of the rest of the world, that is, an adverse shock to "tastes." The shock is assumed to be temporary in nature and to follow an AR(1) process with a half-life of five years. The size is calibrated such that net exports are initially reduced about 10 percent ( 2 percent of GDP).

Figure 1. Macroeconomic response to a decline in the demand for Colombian exports under different policy responses
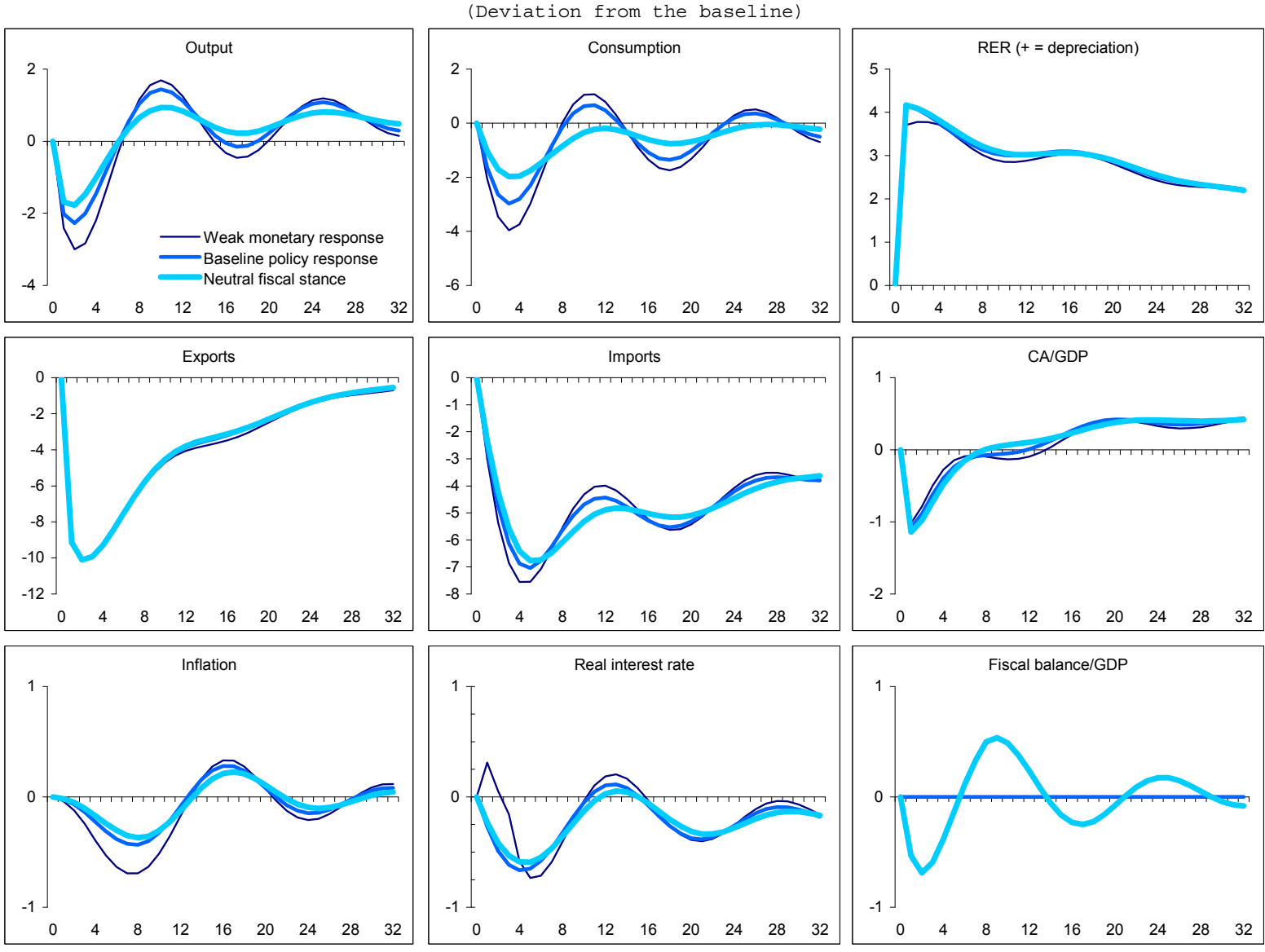

19. The decline in foreign demand for Colombian exports provokes a contraction in output and a real depreciation. In particular, in the first year, the real exchange rate depreciates by about 4 percent, while output deteriorates about 13/4-3 percent, depending on the policy response. The depreciation, as well as the temporary nature of the shock, leads to a recovery of exports over time. Imports decline following the depreciation, owing to a decline in household consumption, but not enough to avoid a deterioration in the current account deficit of about one percentage point of GDP. Given Colombia's ample level of reserves (about 10 percent of GDP) and relatively low level of external debt (about 20 percent of 
GDP), the increase in the current account deficit could easily be accommodated, under the assumption of normal financing conditions.

\section{A rapid easing of monetary policy softens the effect of the shock on output and}

contributes to further depreciation. The baseline policy response-which seeks to replicate the typical response of the Banco de la República to a decline in output-implies a reduction in real interest rates of about 65 basis points in the first year. ${ }^{10}$ To illustrate how such a policy helps stabilize macroeconomic aggregates, a weaker monetary response - simulated by reducing the speed of adjustment of nominal rates during the first year-is also simulated. ${ }^{11}$ Under the assumption of a more sluggish monetary policy response, there is a sharper decline in output and consumption in the initial years, an increase in output volatility in the medium term, and the need for an even stronger monetary response to stabilize output in the long run.

\section{Under normal financing conditions, allowing the budget deficit to rise in} response to the shock also helps reduce short-run output losses. Fiscal policy can play an important role in stabilizing macroeconomic aggregates. To illustrate this point we simulate a neutral fiscal stance, ${ }^{12}$ which implies a deterioration in the fiscal deficit-owing to the reduction in output and decline in revenues — of almost $3 / 4$ percent of GDP. This fiscal response reduces the decline in output by about $1 / 2$ percentage point and household consumption by about 1-percentage points for the first year. At the same time, it lowers the volatility in both aggregates over the medium-term.

\section{Case 2: a decline in global growth of two percentage points}

\section{The decline in global growth reduces} output in Colombia by about $1 / 2$ percentage point. A temporary increase in the preference for savings in the rest of the world leads to the decline in growth. The decline is reversed due to an ease of monetary policy in the rest of the world, and as the preference shock dies out. In Colombia, the exchange rate appreciation and the monetary policy easing helps to ameliorate the impact by allowing for higher consumption

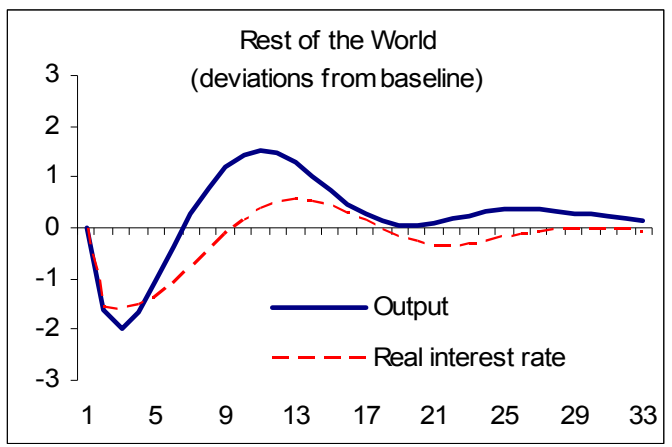
and imports, and the corresponding current account deficit. A neutral fiscal policy, by

\footnotetext{
${ }^{10}$ The model assumes a monetary policy reaction function similar to that in the Banco de la República's MMT. Fiscal policy is assumed to follow a constant deficit rule.

${ }^{11}$ The coefficient of persistence of nominal rates is increased to .99 in the first and second quarters following the shock and to .75 in the third and fourth quarter. The coefficient is set to 0.5 in the following years.

12 The constant deficit rule assumed under the baseline policy response is procyclical, as the decline in taxes resulting from the reduction in output would need to be matched by spending cuts.
} 
allowing a decline in the fiscal deficit as tax revenues decline along with the slowdown in output and consumption, helps ease the effect of the shock on growth.

23. The model suggests that Colombia is well suited to deal with these shocks. The decline in Colombian output growth during the first year of the shock is between a quarter and a third of that in the rest of world under the inflation targeting framework. This finding is roughly in line with Banco de la República (2008) which focuses on the effect of a global slowdown through trade links. The result is somewhat at odds with Abrego and Osterholm (2008) which estimate that a shock to world growth would imply a 40 percent larger decline in Colombian growth. However, their estimates are based on a Bayesian VAR that also includes the impact realized through financial linkages.

Figure 2. Macroeconomic response to a decline in the world growth (higher preference to save)
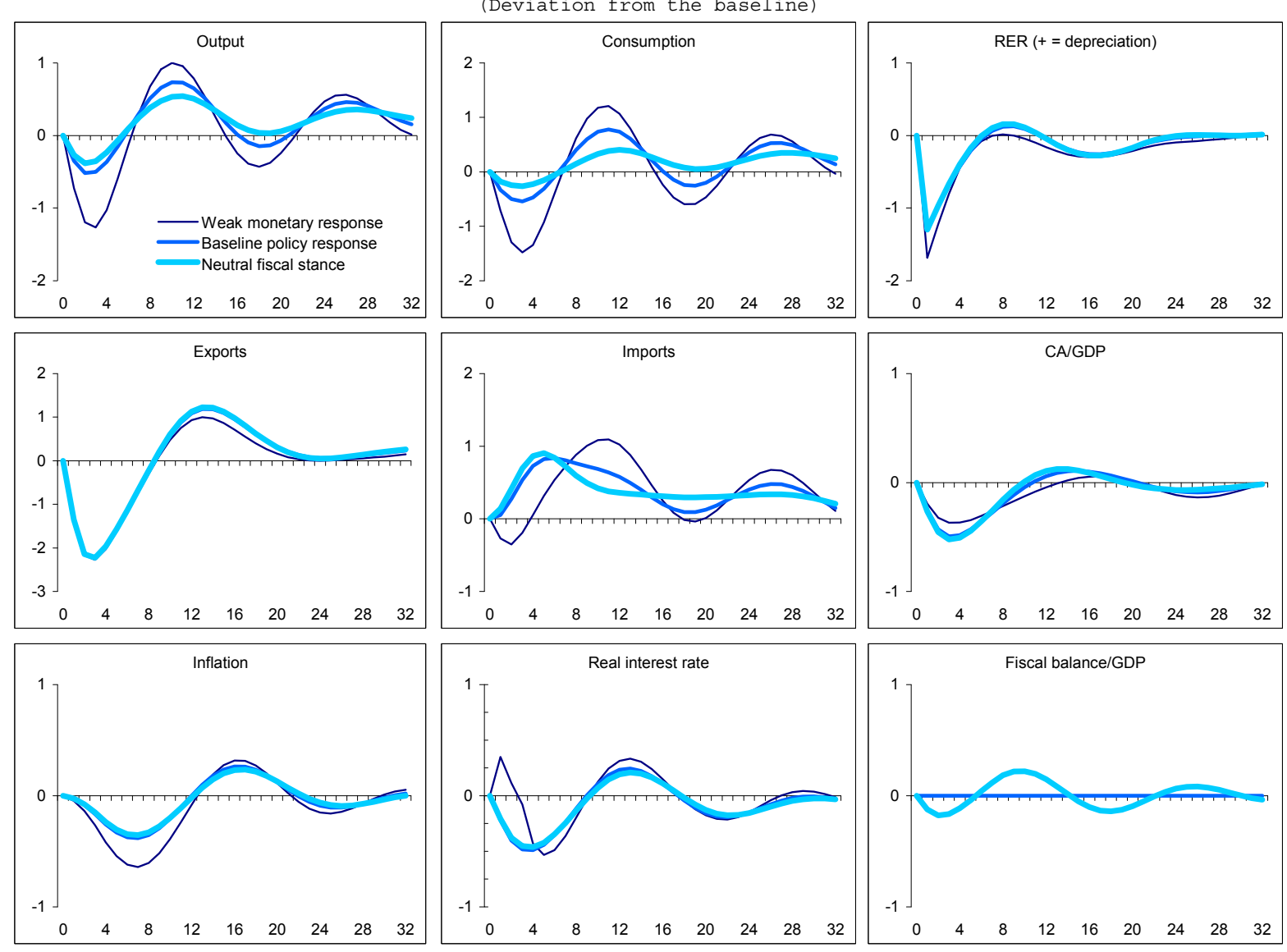


\section{Case 3: An increase in the risk premium}

\section{This scenario assumes an exogenous $\mathbf{1 0 0}$ basis point increase in the risk}

premium. The increase in $\delta_{1}$ (equation 3 ) is assumed to follow an $\mathrm{AR}(1)$ process with a half-life of $1 \frac{1}{2}$ years. The increase in the risk premium implies a decrease in the risk-adjusted return on Colombian bonds, which, via arbitrage, lowers demand for Colombian assets and induces currency depreciation.

\section{The real depreciation triggered by the increased risk premia has an inflationary} effect, which prompts a tightening of monetary policy. The inflationary pressure is in part offset by deflationary pressures associated with the decline in aggregate demand. The higher cost of borrowing from the rest of the world depresses consumption and increases the cost of capital. This reduces the profitability of private capital and dampens investment. The depreciation also leads to higher exports and lower imports in order to improve the external account and the international investment position. The overall decline in private spending also improves the external current account balance. Over the medium run, stabilizing net foreign liabilities requires a weakening of the trade balance, an adjustment that implies an exchange rate appreciation.

Figure 3. Macroeconomic response to temporary increase in risk premium
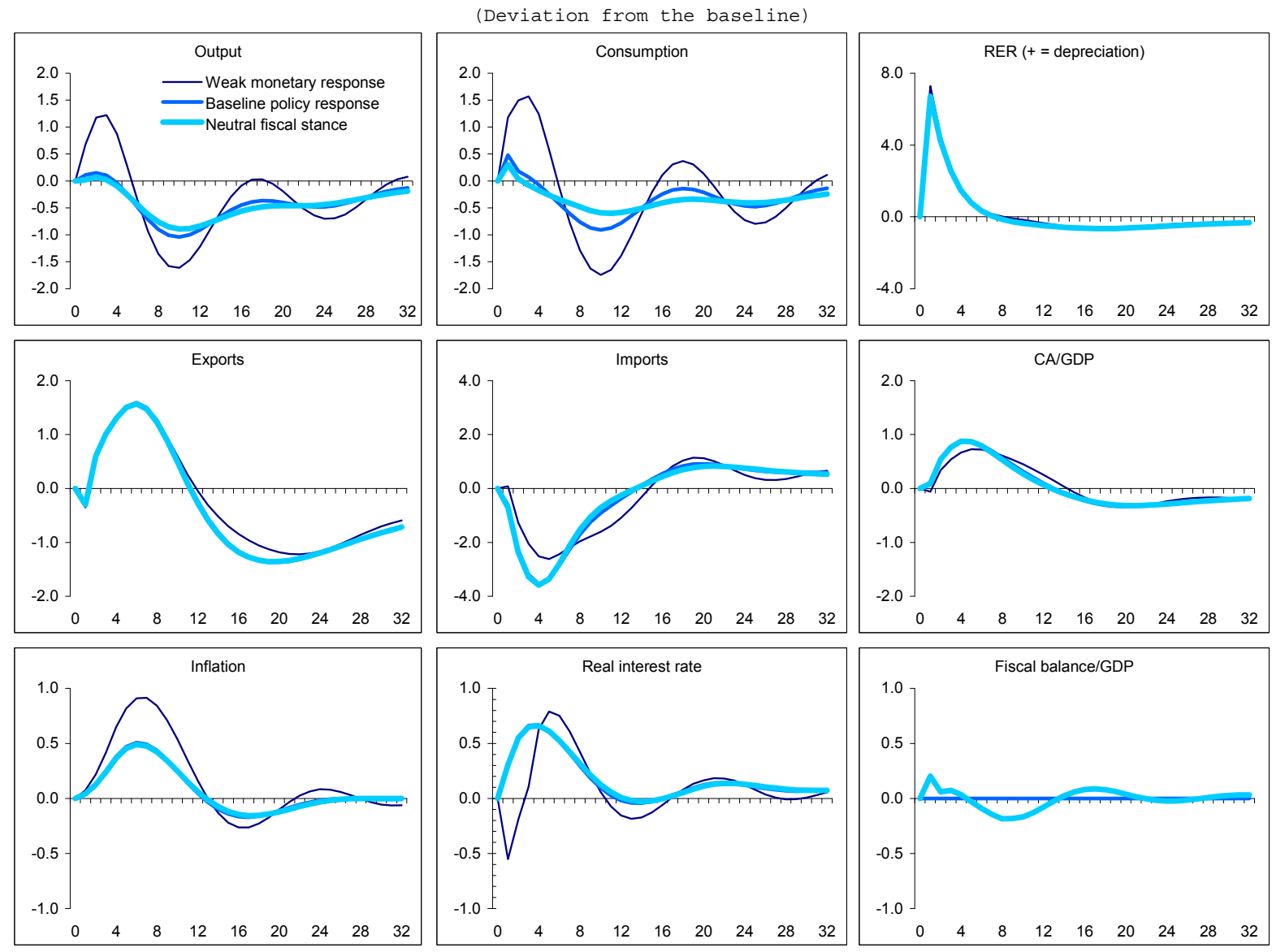
26. The increase in the risk premia has a long-lasting effect on output. In some ways, the increase in the risk premia acts like a supply shock, as the depreciation of the currency leads to an increase in inflation while also reducing output. The increase in inflation also requires a tightening of monetary policy to return inflation to the long-run target. Output returns to the baseline level after a very long period. These results underscore the importance of the risk premia and financing conditions for macroeconomic stability, which are further explored in section D.

27. Monetary policy helps to ameliorate the shock. The increase in real rates is smaller than the increase in the risk premium, which reduces the impact of the negative shock. The simulations suggest that a more pronounced easing of monetary policy (as under the "weak monetary policy response") would be ill-advised, as this exacerbates the inflationary pressures generated by the devaluation. With a weak response in the immediate aftermath of the shock, an even stronger tightening would be needed later, and an even deeper decline in output.

28. Under a shock to the risk premia, a cyclically neutral fiscal stance is not very effective in helping stabilize output. As indicated in Figure 3, the return of output to the baseline is largely similar under both the neutral fiscal stance and a stance in which the deficit is unchanged. The reason is that under such a scenario, there is a tradeoff between the objectives of returning inflation toward the long-term target and stabilizing output. In the case where the fiscal stance is neutral, monetary policy is tighter than under the baseline, offsetting the effect of automatic stabilizers on economic activity.

29. This analysis has important implications in the context of the recent increase in global risk aversion. Under this kind of shock, accommodative fiscal policy may not be effective. The results also foreshadow the analysis in the following section, where we assess the effect of the risk premia on the effectiveness of fiscal policy in responding to a trade shock.

\section{The Role of Fiscal Policy Under Different Financing Conditions}

30. The effectiveness of fiscal policy is linked to the availability of financing and the credibility of the fiscal framework. In this section, we assess the effectiveness of fiscal policy by combining a trade shock with an exogenous shock to the risk premia.

Case 1: Exogenous shock to the external environment

31. The effects of fiscal policy depend on financing conditions. To assess this, we simulate the effects of different fiscal policy responses to a trade shock (as envisaged in case 1), but under adverse financing conditions. To simulate this we add a relatively sharp (350bp) but short-lived (half-

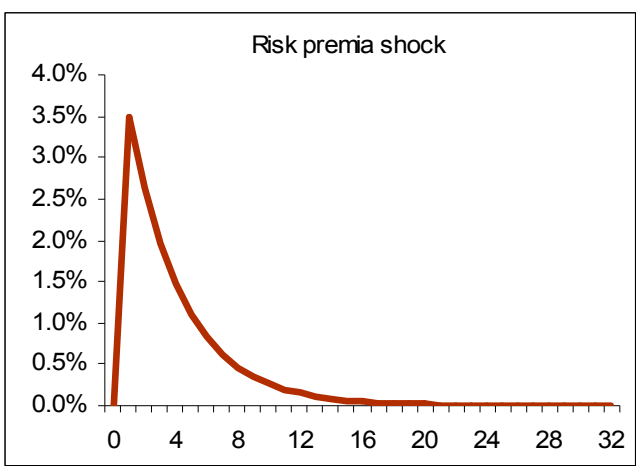


life of $1 / 2$ year) risk premium shock. This helps simulate the situation confronted by many emerging market countries - including Colombia - in the current global context, where export growth is projected to decline while sovereign debt spreads, as well as long-term interest rates for government bonds, have risen. In effect, the analysis attempts to combine elements of both case one (the trade shock) and case three (the risk premia shock) discussed above.

\section{Under the scenario of both a trade shock and increase in risk premia,}

inflationary pressures increase. Under normal financing conditions, the trade shock leads to a small devaluation; but inflationary pressures are not high, as the trade shock leads to a decline in demand pressures and allows for some room for monetary easing. Under the scenario with adverse financing conditions, however, the devaluation and accompanying inflationary pressures are quite large. Although domestic demand initially declines in this scenario, the increase in inflation allows for little scope for monetary accommodation. Under normal financing conditions, the trade shock would lead to an increase in the current account deficit. With the combined shocks, the devaluation is large enough to lead to an improvement in the current account balance.
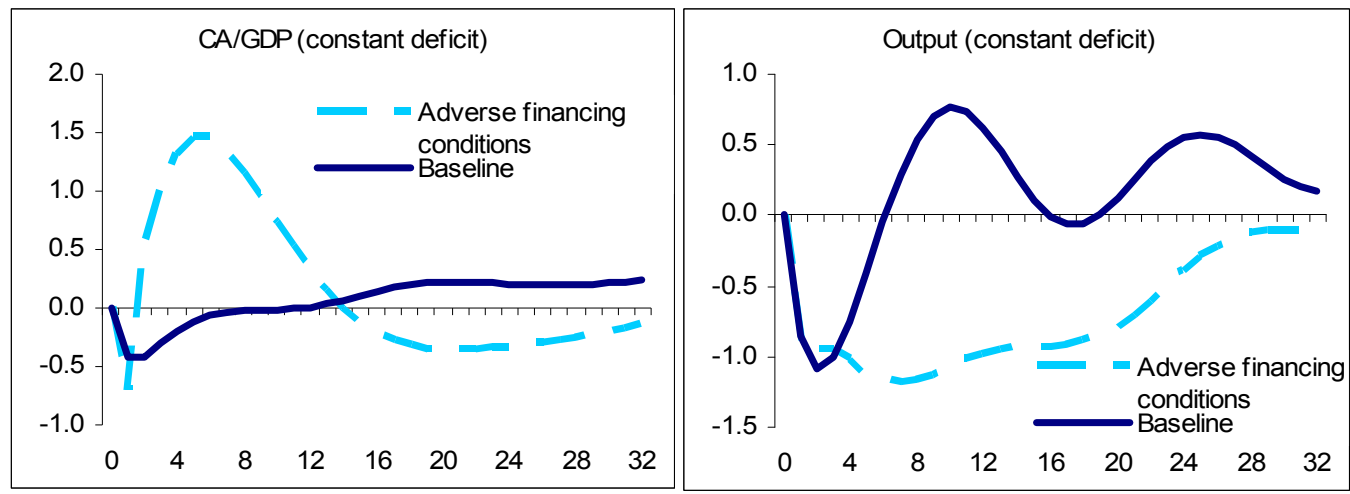

\section{Adverse financing conditions also hinder the effectiveness of fiscal policy in}

responding to a trade shock. Under normal financing conditions, a neutral fiscal policy reduces the squared deviation of output from the steady state by 44 percent, compared to a constant deficit rule. Under adverse financing conditions, the reduction is less than 1 percent, implying that fiscal policy is of little help in stabilizing output. ${ }^{13}$ The reason for this is broadly similar to that described under the case of an increase in the external risk premia in case three above: an increase in the budget deficit is at cross purposes with monetary policy and the objective of bringing inflation back toward the long-run target.

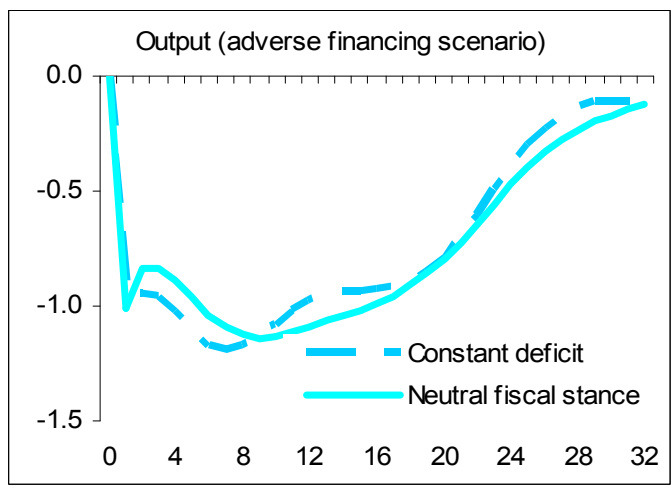

${ }^{13}$ Calculated for the first five years following the shock. 


\section{Case 2: Credibility problems}

34. Fiscal policy could also be less effective if an increase in the budget deficit itself triggers an increase in risk premia. The prospect of a higher budget deficit and public financing requirement may alter expectations about the government's commitment to its long-term fiscal targets and lead to somewhat higher interest rates. We simulate this with a small (15bp) but rather long-lived (5-year half-life) increase in the risk premia. In these circumstances, the policy choice we simulate is either to maintain a constant deficit or a neutral stance. We then show the effect on output and consumption when an accommodative fiscal stance (in response to a trade shock) is undertaken in favorable financing conditions, and when the increase in the deficit triggers a higher risk premium. The results suggest that even a small increase in the risk premia - if long-lived — can render fiscal policy largely ineffective. This underscores the importance of a credible medium-term fiscal policy framework to help anchor market expectations regarding the government's commitment to fiscal targets over the longer term.
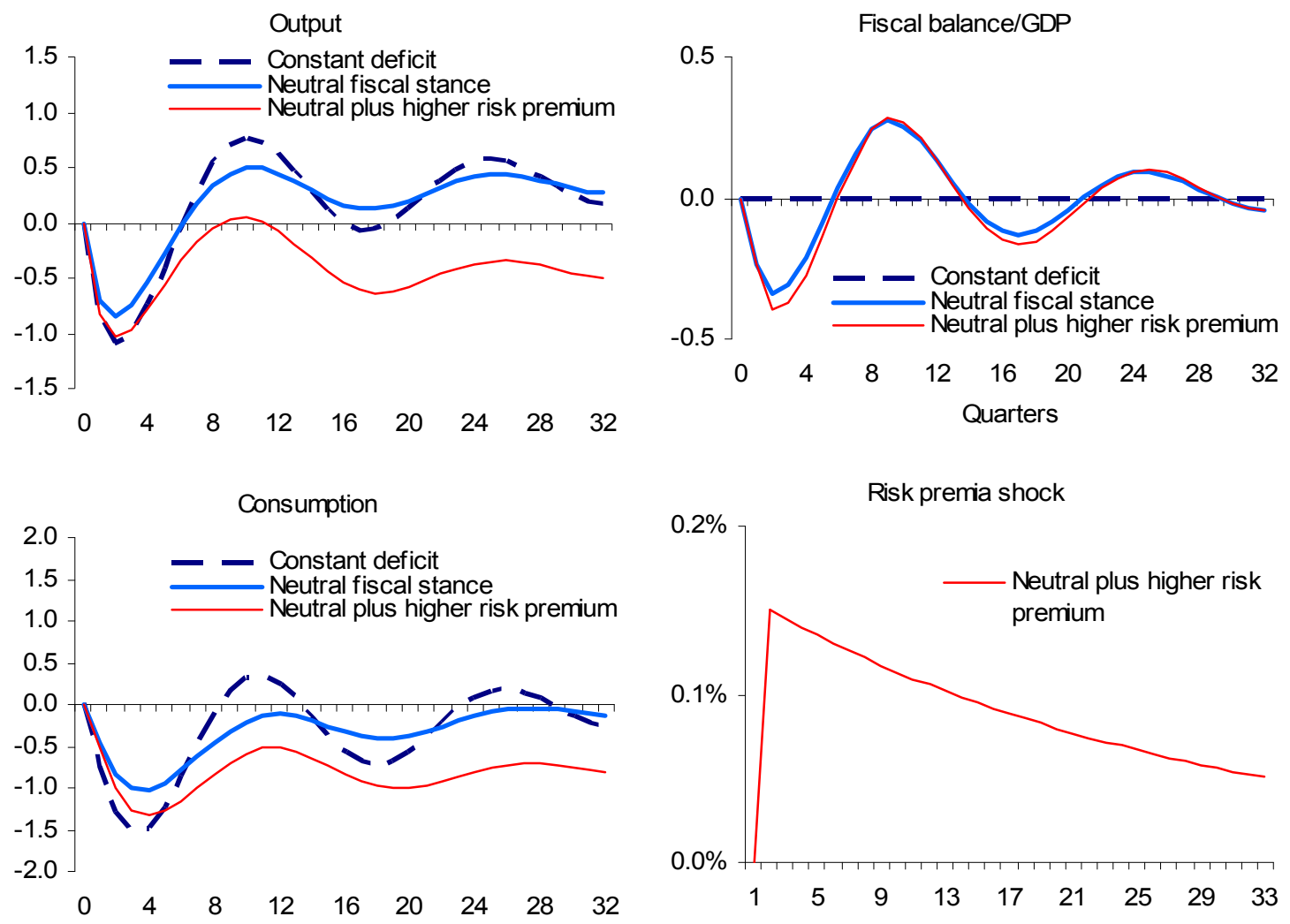

35. The results depend on the size and duration of the financing shock that is incorporated into the analysis. If the risk premia shock is of very short duration and of a small size, then there may still be a case in favor of allowing the automatic stabilizers to work; to the extent that the risk premia shock is long-lived or large, the effectiveness of fiscal policy is hampered. 


\section{E. Summary of Policy Implications}

36. External shocks can have a significant effect on key macroeconomic variables, but with a flexible exchange rate and an agile response by monetary policy, the adverse effects are manageable. The simulations presented in the paper, using the GIMF, indicate that all three of the simulated shocks - an exogenous reduction in export demand, a decline in world growth, and an increase in risk premia - would each have a significant effect on growth in the short run. At the same time, the rapid response of monetary policy along with a flexible exchange rate help to limit the adverse effects on output losses, consumption and the external accounts.

\section{The potential role of fiscal policy in responding to external shocks depends on}

financing conditions. The simulations indicate that adopting a cyclically neutral stance can reduce the output costs of external shocks under normal financing conditions. If financing conditions are adverse, then the case in favor of allowing automatic stabilizers is less clear cut. The results suggest that the case for and against accommodative fiscal policy is an empirical question, and would need to judged cautiously in light of the availability of financing and market expectations. As such, they support the cautious approach taken by the Colombian authorities to assess the merits of changing the fiscal targets under the scenario of a more adverse global environment. 


\section{References}

Abrego, Lisandro, and Pär Österholm, 2008, "External Linkages and Economic Growth in Colombia: Insights from a Bayesian VAR Model," IMF Working Paper WP 08/46 (Washington: International Monetary Fund).

Banco de la República, 2008, Informe de Inflación (March).

Gómez, Javier, José Darío Uribe, and Hernando Vargas, 2002, “The Implementation of Inflation Targeting in Colombia," Borradores Semanales de Economía, No. 202.

Kumhof, Michael, and Douglas Laxton, 2007, “A Party Without a Hangover? On the Effects of U.S. Government Deficits,” IMF Working Paper No. 07/202 (Washington: International Monetary Fund).

Leigh, Daniel, 2008, “Achieving a Soft Landing: The Role of Fiscal Policy,” IMF Working Paper WP/08/69 (Washington: International Monetary Fund).

López, Martha, 2003, "Efficient Policy Rules for Inflation Targeting in Colombia," Borradores Semanales de Economía, No. 240. 


\section{Are Capital Controls Effective in the $21^{\text {sT }}$ Century? The Recent EXPERIENCE OF COLOMBIA ${ }^{1}$}

\section{A. Introduction}

1. The Colombian experience with capital controls has sparked a lively debate, but one which is far from settled. Confronted with rapid currency appreciation and a surge in capital inflows, controls were imposed in May 2007, and removed during the market turbulence of October 2008. Capital controls are not new in Colombia, having first been imposed in the 1990s. Research on Colombia points to a similar experience as in other countries: controls have been ineffective in altering the real exchange rate, while nevertheless enhancing the independence of monetary policy. Regarding the most recent episode, the observed decline in net private capital inflows after their imposition would appear to suggest that the controls were effective (Vargas and Varela, 2008). Cardenas (2007), however, concludes that the controls had no independent effect on total net private capital inflows, based on an econometric model that takes account of other determinants of these movements. Galindo (2007) and Concha and Galindo (2008) conclude that the controls have had a transitory effect on net private capital inflows, but without significant effects on the real exchange rate.

2. This paper attempts to add to this literature by assessing the effect of the recent controls on capital flows and the exchange rate, while addressing a number of

unresolved issues. First, additional study is needed on the effects of the controls on separate categories of capital inflows. Second, most—if not all—assessments of the effects of capital controls have focused on their impact on net, rather than gross, flows, including recent studies (Cardenas, 2007; Concha and Galindo, 2008). A disaggregation of the effects on both inflows and outflows could potentially yield rich insights into how the controls affect capital markets. While the controls were imposed on gross inflows, they may also have affected outflows, owing to the effect of the new limits imposed on derivative positions and the need of some market participants to unwind their positions. Third, there is scope to more precisely quantify the effects of the controls on the exchange rate, which has received relatively less attention in recent studies.

\footnotetext{
${ }^{1}$ Prepared by Benedict Clements and Herman Kamil.
} 
3. The analysis in this paper focuses on an assessment of the effectiveness of capital controls, but not their costs and benefits. The paper does not analyze the microeconomic costs of controls or their adverse effects on market development. It also does not assess the potential role of the controls in helping protect financial stability by reducing the risk associated with the sudden reversal of inflows. At the same time, the analysis provides an assessment of the impact of the controls on capital flows, which could be drawn upon for a broader assessment of the effects of controls on financial stability.

4. This paper is organized as follows. First, a description of the database used for the study, and developments in exchange rates and capital flows in the periods immediately preceding and following the introduction of capital controls, is provided. This section also includes a description of the controls imposed in Colombia in May 2007. Second, the empirical methodology used to isolate and measure the effects of the controls is described. Third, the empirical results are given, followed by a summary section that also includes suggestions for further research. An appendix provides a review of the literature on capital controls, focusing on studies assessing the Colombian experience.

\section{B. Database and Stylized Facts on Capital Flows and Exchange Rates}

\section{Database}

5. The data used in this study capture all capital account transactions by the private sector that are intermediated in the foreign exchange market and recorded by the Banco de la República (BdR). Data on foreign exchange flows are derived from the BdR's balanza cambiaria (foreign exchange balance). The categories of foreign exchange transactions included are external borrowing, portfolio investment, foreign direct investment (FDI), and other movements that involve changes in bank accounts held abroad by residents and registered at the $\mathrm{BdR}$ (cuentas corrientes de compensación). They exclude capital account transactions that are undertaken without an exchange of currency (e.g., certain forms of FDI).

\section{The balanza cambiaria data includes foreign currency transactions between}

residents. Traditional balance of payments data only capture transactions between residents and nonresidents. In contrast, these operations are included in the balanza cambiaria data. For example, when a Colombian pension fund acquires foreign exchange to purchase a dollar-denominated bond owned by a Colombian investment fund, this is registered as a foreign exchange outflow. If the investment fund takes these dollars and converts them into pesos, this would be registered as an inflow. Thus, on a gross basis, the balanza cambiaria data tend to indicate a greater level of transactions than balance of payments data, although on a net basis, they present a similar picture. 
7. The data is available on a weekly basis, which makes them an attractive source of information for studying the short-term behavior of capital flows. Because of its broad coverage and availability at high frequency, these data have also been employed in other studies assessing Colombia's experience with capital controls (Concha and Galindo, 2008).

\section{Capital flows and exchange rates in the pre-controls era}

8. Following the turmoil in global markets in mid-2006, the peso appreciated significantly in the second half of the year. ${ }^{2}$ The peso recovered steadily from July through December, appreciating by about 9 percent in nominal effective terms. With the BdR beginning a period of monetary tightening (commencing in April 2006) to address overheating concerns, interest rate differentials also began to rise. Net FDI inflows were strong, while net non-FDI flows remained muted.
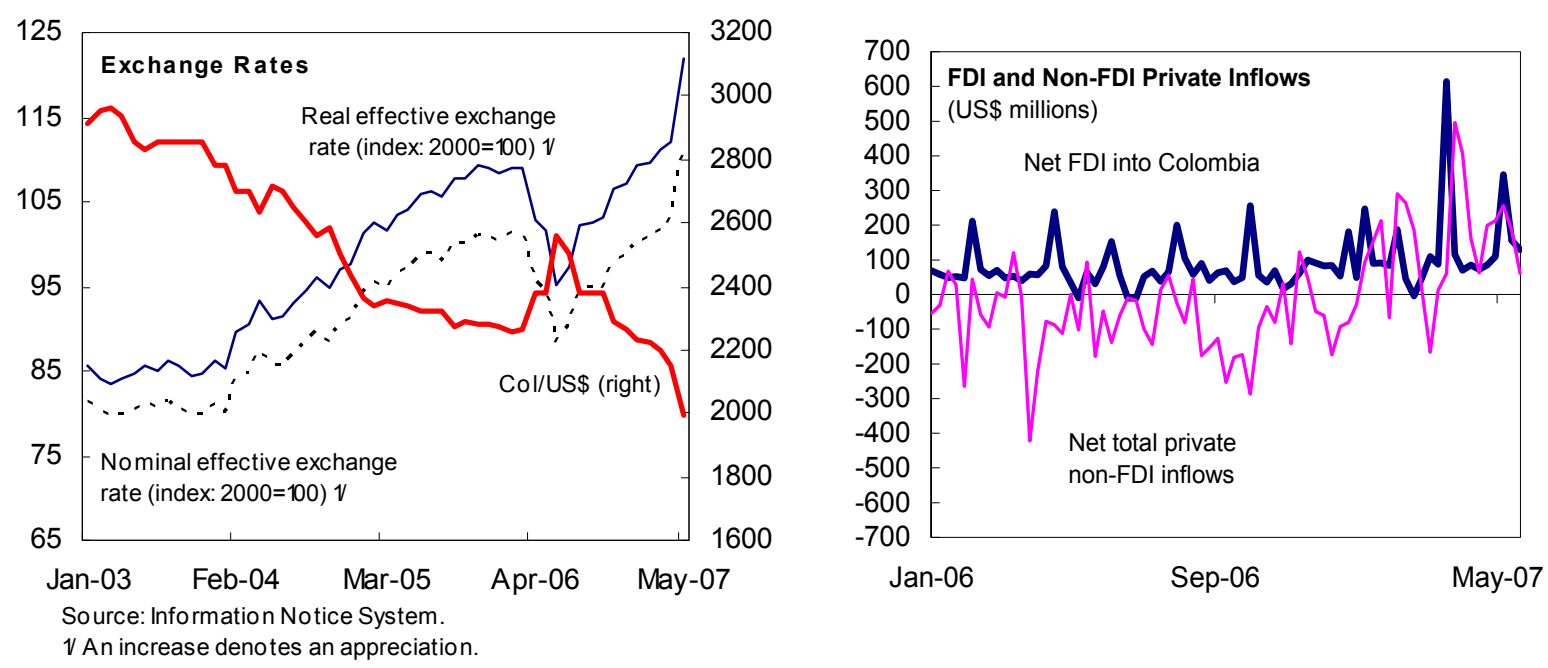

9. Non-FDI inflows increased sharply and the exchange rate continued to appreciate in early 2007. With inflation and inflation expectations rising beyond the BdR's inflation target, policy rates were increased by an additional 75 basis points in the first four months of the year. The exchange rate appreciated an additional 5 percent in nominal effective terms. Gross inflows rose sharply, spurred on by rising interest rate differentials and market expectations of a peso appreciation.

10. Sterilized intervention failed to quell the surging peso. The authorities attempted to resist appreciation pressures with a large dose of sterilized intervention (starting in mid-January 2007), accumulating about 38 percent of base money in the first four months of

\footnotetext{
${ }^{2}$ From mid-December 2004 through mid-June 2006, capital controls were also imposed in the form of a minimum one-year stay for nonresident portfolio inflows.
} 
the year. Nevertheless, with markets expecting even further appreciation of the peso-in part linked to markets' belief that the authorities' commitment to the inflation target would lead to increasing interest rate differentials - the strategy became unsustainable, and the BdR abandoned its policy of discretionary foreign exchange intervention by the end of April 2007. ${ }^{3}$

\section{Capital flows and exchange rates in the controls era}

\section{On May 6, 2007, the authorities introduced capital controls as part of a new} strategy to slow the appreciation of the peso. The primary measure comprised an unremunerated reserve requirement (URR) on external borrowing of 40 percent. This revived the capital controls in place in Colombia between 1993 and 2000. The URR was to be held for six months in the BdR and applied to both the private and public sectors.

\section{As a prudential measure, a ceiling on currency derivative positions was also}

imposed. Banks were henceforth required to keep their overall gross positions in these instruments to no more than 500 percent of their capital. Market participants were allowed some time to unwind positions to meet the new ceiling, which became binding on July 4 . The measure addressed prudential concerns based on the high exposures of some banks and potential counterparty risks involved with these large positions. By restricting derivative positions, this measure also potentially affected capital flows and the exchange rate, and helped prevent circumvention of the URR.

\section{The capital controls were extended in late May 2007 to portfolio inflows. With}

portfolio inflows accelerating the first weeks of May, the URR was extended on May 23 to portfolio inflows by foreign residents. Investors were given the option of early withdrawals of funds from the URR, but with substantial penalties, ranging from 9.4 percent of the reserve requirement (for immediate withdrawals) to 1.6 percent (if held for 5 months).

\section{Colombian institutional funds, including pension funds, were excluded from the} capital controls. The exclusion of the pension funds is of particular importance, as they are highly active in trading in the foreign exchange market (Gómez, Jara, and Murcia, 2006). Their exclusion is also important in light of the fact that Colombian residents and firms, rather than nonresidents, accounted for about three-fourths of portfolio inflows in the precontrols era. In addition, in June 2007, an exemption was granted for equities issued abroad. This effectively exempted from the controls the issuance of stock through American Depository Receipts (ADRs).

\footnotetext{
${ }^{3}$ See Kamil (2008) for an analysis of the effectiveness of intervention policies in Colombia during this period. Kamil and Reveiz (2008) provide further elaboration on the relationship between sterilized intervention and carry trade in Colombia.
} 
15. Capital controls regulations underwent a further series of changes, beginning in late 2007, and were eliminated in October 2008. Controls were relaxed in December 2007, as the URR for initial public offerings of equities was eliminated, and penalties for early withdrawal of funds were reduced by about 40 percent. Controls were subsequently tightened in May of 2008, as the URR on portfolio inflows was raised from 40 percent to 50 percent, and a minimum stay of two years was imposed on FDI. ${ }^{4}$ Also in May, the limit on gross derivatives positions was increased from 500 percent of capital to 550 percent. In June, the penalty for early withdrawal of deposits under the URR (which had previously been relaxed in December of 2007) was also raised. Controls were subsequently loosened in September as the minimum stay requirement on FDI was revoked, and purchases of equities were exempted from the URR. In October, the capital controls were eliminated, although the limit on the derivative position of banks of 550 percent of capital remained.

\section{Several aspects of the nature of private capital flows in Colombia are worth} noting when analyzing the potential effects of capital controls. In net terms, FDI accounts for the vast majority of inflows (Table 1). In the pre-controls era, for example, FDI accounted for 96 percent of net private inflows, as net non-FDI flows had been close to zero. FDI was not targeted by the controls - except in the later period, via a minimum stay rule. Second, portfolio flows by residents are substantially more important than nonresidents, in gross terms; in net terms, however, the opposite is the case. Third, for resident portfolio flows, the weekly net movements are dwarfed by the size of gross inflows (net are between 2 and 8 percent of gross, depending on the period). Fourth, gross flows - which are several orders of magnitude of net flows - are inflated by the high level of transactions between residents that involve offsetting transactions involving both inflows and outflows, especially for portfolio flows between residents. ${ }^{5}$ Indeed, as Figure 1 demonstrates, periods of high inflows have corresponded to periods of high outflows.

\section{A comparison of mean weekly gross inflows across periods suggests that the} effects of the controls was strongest for foreign borrowing and portfolio inflows from non-residents, but its overall effect on non-FDI gross inflows was insignificant. Table 1 provides mean statistics for weekly average flows across different categories. The table also reports tests for the equality of first moments between the capital control period (May 2007-

\footnotetext{
${ }^{4}$ This followed less important extensions of the controls in end-April that broadened the coverage of transactions classified as foreign borrowing (and hence subject to the URR). These included (1) import financing of greater than six months (financing of capital goods and loans under US $\$ 10,000$ were excluded); and (2) credit obtained from abroad by Colombian firms for the purpose of financing outward FDI.

${ }^{5}$ This can be seen be the high correlation (about 90 percent) between Colombian resident portfolio inflows and outflows.
} 
July 2008) and the immediate pre-controls era (July 2006 to April 2007). ${ }^{6}$ Means tests indicate the controls have been associated with statistically significant reductions in foreign borrowing and nonresident portfolio gross inflows. Combined, these two categories accounted for about 11 percent of average total gross inflows in the pre-controls era. With respect to other flows, we find that portfolio inflows of Colombian residents have actually increased relative to the pre-controls era, while FDI inflows have also been higher.

\footnotetext{
${ }^{6}$ This pre-controls era captures a period when international markets were relatively calm and during which interest rate differentials in Colombia, vis-à-vis the rest of the world, started to rise. Thus, it represents a good period for establishing a baseline before the start of the capital controls.
} 
Table 1. Colombia: Private Capital Flows Before and After Capital Controls

(Weekly average flows in US\$ millions)

\begin{tabular}{|c|c|c|c|c|}
\hline Category & Type of flow & Before 1/ & After 2/ & $\begin{array}{c}\text { Change in } \\
\text { Average } \\
\text { (After minus } \\
\text { Before) } \\
\end{array}$ \\
\hline \multirow[t]{2}{*}{ Total } & Net inflows & 99.6 & 104.9 & 5.3 \\
\hline & Gross inflows & 671.1 & 727.7 & 56.7 \\
\hline \multirow[t]{2}{*}{$\underline{\text { Total non-FDI }}$} & Net inflows & 3.7 & -32.8 & -36.4 \\
\hline & Gross inflows & 565.6 & 580.6 & 15.0 \\
\hline \multirow[t]{2}{*}{ Borrowing } & Net inflows & -10.8 & -17.1 & -6.3 \\
\hline & Gross inflows & 41.1 & 17.1 & $-24.1 * * *$ \\
\hline \multirow[t]{2}{*}{ Portfolio (Non-residents) } & Net inflows & 25.2 & -3.6 & $-28.8^{* * *}$ \\
\hline & Gross inflows & 31.9 & 9.9 & $-22.0 * * *$ \\
\hline \multirow[t]{2}{*}{ Portfolio (Colombian residents) } & Net inflows & -4.7 & -18.1 & -13.3 \\
\hline & Gross inflows & 155.9 & 227.5 & $71.5^{* * *}$ \\
\hline \multirow[t]{2}{*}{ Drawdown of bank accounts abroad } & Net inflows & -0.9 & 0.3 & 1.2 \\
\hline & Gross inflows & 347.4 & 320.6 & -26.9 \\
\hline \multirow[t]{2}{*}{$\underline{\text { FDI }}$} & Net inflows & 95.9 & 137.7 & $41.8 * *$ \\
\hline & Gross inflows & 105.5 & 147.6 & $42.2 * *$ \\
\hline \multicolumn{5}{|l|}{ Memorandum items 3/: } \\
\hline Total ( percent of GDP) & Net flows & 2.8 & 2.4 & \\
\hline Total non-FDI ( percent of GDP) & Net flows & 0.1 & -0.8 & \\
\hline Total non-FDI ( percent of GDP) & Gross inflows & 16.0 & 13.4 & \\
\hline
\end{tabular}

Note: $* * * * *$, and $*$ indicate that average flows in the post control period are statistically significantly different from the pre-control period, at the $1 \%, 5 \%$, and $10 \%$ levels, respectively.

1/ Average flow for the period July 6th, 2006 to May 6th (for portfolio May 23rd) , 2007.

2/ Average flow for the period May 7th (for portfolio May 24th), 2007 to Jul 4th, 2008.

3/ Average weekly flows, annualized as a share of GDP. 
Figure 1. Colombia: Private Capital Flows Before and After Capital Controls (weekly, in US\$ millions)
Inflows
Outflows
$\square$ Net
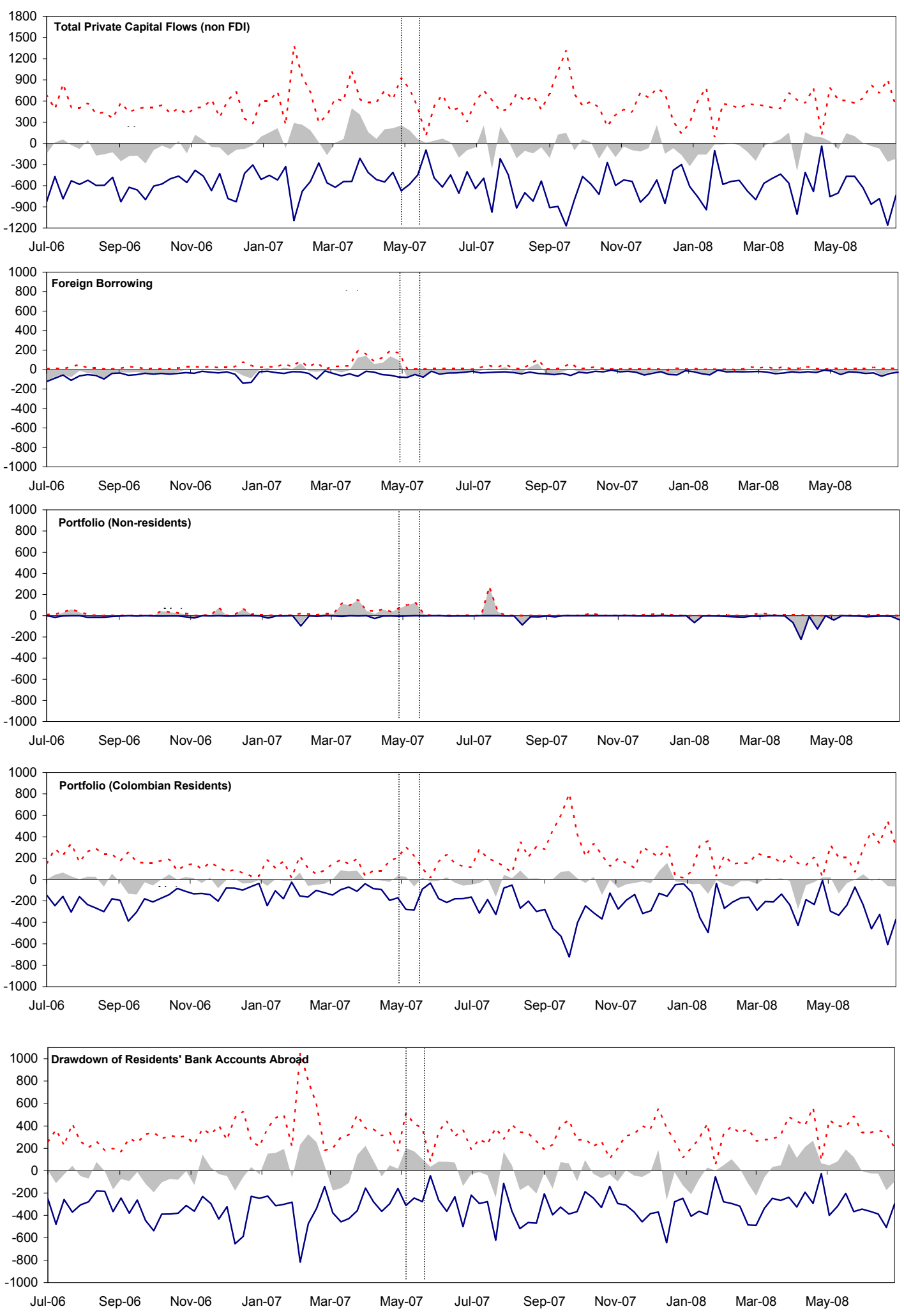

Note: The dashed lines correspond to the dates when capital controls were first imposed in 2007 (May $6^{\text {th }}$ and May $23^{\text {rd }} 2007$ respectively). 
18. On a net basis, capital inflows have not declined in the controls era. A statistically significant decline was found for just one subcategory (non-resident portfolio inflows) in net terms. This accounted, during the pre-controls period, for about 25 percent of net inflows. For foreign borrowing, resident portfolio flows, and the drawdown of bank accounts abroad monetized in local foreign exchange markets, the changes were statistically insignificant. For combined non-FDI net inflows as a whole, no statistically significant reduction was found. Because of the strong increase in gross inflows, FDI also increased, in net terms, in the controls era.

\section{The capital controls have}

also been associated with an increase in off-shore derivative trading by the pension funds. BdR data suggest that cross-border transactions in foreign currency derivative contracts between domestic pension funds and offshore entities have increased sharply since mid-2007. The average monthly value traded rose from US\$6 million in the pre-control period to an average of about US\$405 million since-over a 60 -fold increase. ${ }^{7}$ The average monthly value of contracts traded between off-shores and local banks, on the other hand, increased much more modestly ( 250 percent). The reallocation of this activity to the pension funds was probably a consequence of the ceiling of derivative positions imposed on local financial institutions, which may have led to an increase in the role of the offshore sector in providing currency hedges to the pension funds ${ }^{8}$. This may also help explain the observed increase in gross weekly inflows for Colombian residents and institutions since May 2007, while their net position has stayed roughly unchanged.

\footnotetext{
${ }^{7}$ This reached US\$800 million in July 2008.

${ }^{8}$ Another reason may have to do with the implementation of an unremunerated reserve requirement on new deposits that was also implemented in May 2007. While not part of the capital controls per se, this encaje marginal constrained the ability of local banks to offer forwards to pension funds, as it reduced their liquidity and thus their ability to hedge their forward currency transactions.
} 


\section{The exchange rate continued to} appreciate after the implementation of capital controls. The capital controls were not associated with an immediate effect on the exchange rate, which continued to appreciate until a period of brief global turbulence in June-August 2007. Afterwards, the peso resumed its upward climb, spurred on by the global weakness of the dollar, strong FDI flows, and improving terms of trade. From the start of the controls to end-July 2008, the bilateral rate appreciated by 16 percent. ${ }^{9}$

\section{Simple comparisons of the pre-controls} and controls era do not take into account changes in the domestic and external environment that may also have affected capital flows and exchange rates. On the domestic front, these included the BdR's decision to refrain from discretionary foreign exchange intervention, and the further tightening of monetary policy, which increased interest rate differentials. Exchange rate volatility also increased, reducing the appetite of foreign investors seeking to exploit interest rate differentials. Externally, EMBI spreads increased, and the VIX - a measure of volatility in international markets - also rose. At the same time, commodity prices rose, strengthening Colombia's trade balance, while a favorable environment for FDI and an improved security situation also helped bolster the peso. In this light, a proper assessment of the effect of the capital controls requires the development of a model that accounts for these changes in the determinants of capital flows, as attempted in Section D below.
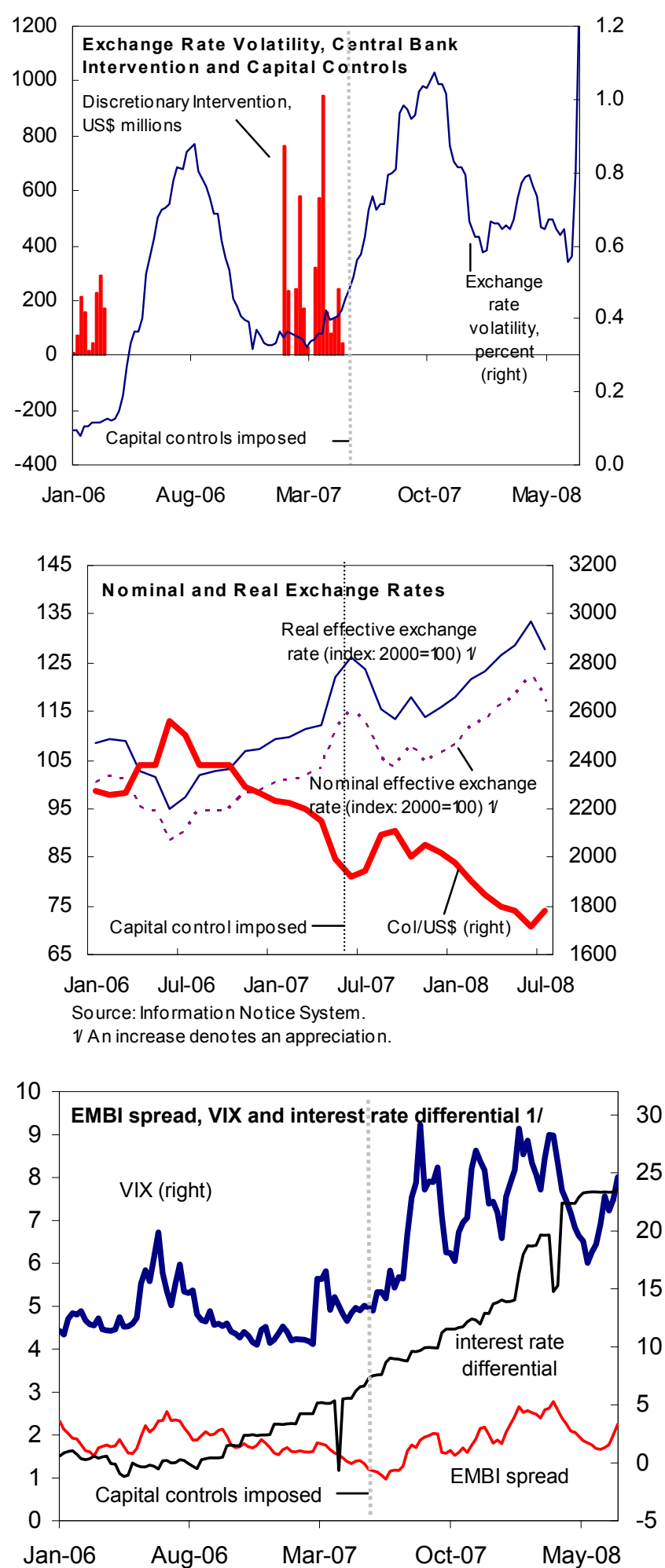

$1 /$ Interest rate differential is the difference between domestic interbank rate and Fed funds rate

\footnotetext{
${ }^{9}$ Following the weakening of commodity prices and global financial turbulence, the peso, like many other emerging market currencies, depreciated sharply in the second half of 2008.
} 


\section{Empirical Methodology}

22. The empirical analysis is based on econometric models of capital flows and the exchange rate. An OLS model is developed to assess the determinants of capital flows on a weekly basis, using the balanza cambiaria data. For the exchange rate model, daily data are used to construct a GARCH model, drawing on Kamil (2008). Capital controls are then assessed in the context of these models that control for the underlying determinants of capital flows and the exchange rate. Both the capital flows and exchange rate models are estimated using data spanning from end-July 2006 to early July 2008.

\section{The focus of the analysis on both net and gross capital inflows represents a} significant departure from previous work for Colombia and other emerging markets. Both flows are important to assess, as they provide different insights. Net inflows, which have traditionally been the focus of previous studies, are often seen as the clearest signal of demand pressures on the domestic currency. At the same time, gross inflow data also offer important insights for exchange rate determination, as each gross transaction provides an opportunity for the underlying asset to be repriced. The econometric results from the gross flows data - especially for the category of resident portfolio flows - should nevertheless be assessed with caution, for the reasons described earlier. The analysis also draws on more disaggregated data than previous studies. This allows us to exclude FDI flows from the analysis, which is difficult to model on a high-frequency (weekly) basis.

\section{The methodology employed here overcomes many of the econometric problems} of previous empirical work. First, endogeneity issues are much less severe than in many other studies. This owes to the fact that under Colombia's inflation targeting regime, interest rates are set to achieve the inflation target, and capital inflows are fully sterilized. Thus, there is no two-way causality between capital flows and interest rate differentials. Second, in light of the use of high-frequency, weekly data over a relatively short period of time-with no discernable trend - there are no issues related to unit roots in the data. In contrast, studies using lower frequency data over a long period of time must take into account the possible nonstationarity of these series.

\section{Identifying the effects of capital controls nevertheless presents several empirical} challenges that need to be borne in mind when analyzing the results. First, the capital controls - in the form of the URR - was also accompanied by a limit on gross derivative positions. Thus, assessing the separate effect of the URR, and the limit on the derivative position, is particularly difficult, and is beyond the scope of the study. Second, the capital controls were imposed in stages (with the initial controls introduced on May 6 and later in May 23 of 2007). Third, the controls have undergone additional (though minor) modifications, in both December of 2007 and throughout 2008. Given the large number of changes, it was not possible to control, with dummy variables, all of these modifications. 
26. Our explicit focus on assessing the effects of the controls on capital flows differs from earlier studies on the experience of Colombia in the 1990s. Villar and Rincón (2001) argue that the effect of the controls on the quantity of inflows is ambiguous, and thus of less relevance in assessing the impact of the controls. They argue that the controls impose a tax on foreign borrowing that brings about an increase in interest rates, which tends to offset the dampening effect of the controls on inflows. In the context of Colombia's current inflation targeting regime, however, capital controls - even if they effectively place a tax on foreign borrowing - would not necessarily lead to an increase domestic interest rates, which are determined by the BdR in light of inflation objectives. Thus, the capital controls could be expected to affect the quantity of inflows, without any effect on interest rates.

\section{The Effectiveness of Controls: Impact on Capital Flows}

\section{We consider five broad categories of flows: foreign borrowing, portfolio} investment (bond and equity flows), movements that involve changes in bank accounts held abroad by residents (cuentas corrientes de compensación), and total non-FDI flows ${ }^{10}$. We assess the behavior of capital flows for categories not directly covered by the controls (such as the drawdown of bank accounts), given the possibility that the controls could divert carry trade towards these categories of inflows. The analysis is carried out separately for each type of capital flow, and we estimate the following OLS regression:

$$
\begin{aligned}
\text { Flow }_{j, t}= & \delta_{0}+\delta_{1} I N T_{t}+\delta_{2}\left(i-r^{*}\right)_{t}+\delta_{3}(\text { EMBI spread })_{t}+\delta_{4} V O L_{t}+\delta_{5} \text { App }_{t}^{E} \\
& +\delta_{6} D_{t} C_{j t}+\varepsilon_{t}
\end{aligned}
$$

where: Flow ${ }_{j}$ corresponds to the weekly inflow for each category $j$ of capital (either net or gross), in millions of dollars; INT is the weekly amount of the BdR's discretionary intervention in the foreign exchange market, in millions of dollars; $\left(i-r^{*}\right)$ is the weekly average interest rate differential between the domestic interbank rate and the U.S. Fed's fund rate, in percent per year; EMBI spread is the weekly average yield spread on a sovereign foreign currency bond over a comparable U.S. treasury bond in percent per year; $V O L$ is the unconditional volatility of the nominal exchange rate, over the previous three-month period; $A p p^{E}{ }_{t}$ is a proxy for the expected appreciation of the exchange rate, obtained as the weekly average of the percentage difference between the spot and forward exchange rates in onshore non-deliverable forward contracts of 15 to 35 days maturity. As a proxy for capital

10 For total non-FDI, we also analyze the determinants of gross outflows. 
controls, we use a dummy variable (DCC) that takes values of 1 in the weeks after capital controls were imposed and zero otherwise. ${ }^{11}$ The main parameter of interest is $\delta_{6}$, the average impact of capital controls on the weekly level of capital flows. If the imposition of capital controls led to a lower level of capital inflows, then $\delta_{6}$ should be negative and statistically significant.

\section{The Effectiveness of Controls: Evidence from Daily Exchange Rate Data}

\section{To analyze the effects of capital controls on the nominal exchange rate, we} estimate a generalized autoregressive conditional heteroskedasticity (GARCH) model ${ }^{12}$ of the daily peso-dollar exchange rate return with the following general specification:

$$
\begin{aligned}
& \begin{aligned}
\begin{aligned}
\Delta\left(\ln s_{t}\right) & =\mu+\beta_{0} \Delta\left(\ln s_{t-1}\right)+\beta_{1} I N T_{t}+\beta_{2}\left(i-r^{*}\right)_{t}+\beta_{3} \Delta(\text { EMBI spread })_{t}+\beta_{4} V I X_{t}+ \\
& +\beta_{5} \text { Comm }_{t}+\beta_{6} D C C_{t}+\varepsilon_{t}
\end{aligned} \\
\varepsilon_{t} \mid \Omega_{t-1} \sim \mathrm{N}\left(0, \sigma_{t}^{2}\right) \\
\sigma_{t}^{2}=\alpha_{0}+\alpha_{1} \sigma_{t-1}^{2}+\alpha_{2} \varepsilon_{t-1}^{2}+\alpha_{3} I_{t}+\alpha_{4}\left(i-r^{*}\right)_{t}+\alpha_{5} \mid \Delta(\text { EMBI spread })_{t} \mid+\alpha_{6} V_{t}+ \\
\quad+\alpha_{7} \mid \text { Comm }_{t} \mid+\alpha_{8} \text { DCC }_{t}+\sum_{i=1}^{4} \delta_{i} D_{i t}+v_{t}
\end{aligned}
\end{aligned}
$$

where: $\Delta(\ln s)$ is the daily percentage change in the nominal exchange rate (such that a positive change is a depreciation of the Colombian peso); VIX is the implied volatility of the

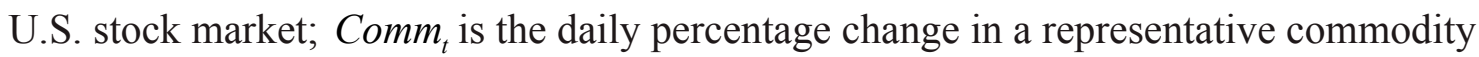
export price index of the Colombian economy, ${ }^{13}$ and the rest of the variables are defined as above. $D_{i t}$ are day-of-the-week dummy variables (for example, $D_{1 t}=1$ for Mondays, where Friday is the omitted category); and || denotes the absolute number operator. $\varepsilon_{t}$ is the

\footnotetext{
${ }^{11}$ For total non-FDI, foreign borrowing, and the net drawdown of bank accounts abroad, the dummy takes on a value of one from May 6, 2007 onward. For portfolio flows, the starting date is May 23.

${ }^{12}$ In all cases a GARCH $(1,1)$ model was estimated as it is typical in the literature. Given the presence of heteroskedastic disturbances in our sample, we use the methods described in Bollersev and Wooldridge (1992) to compute standard errors.

${ }^{13}$ The commodity price index was constructed as a weighted average of daily commodity prices for the main commodities exported by Colombia, using weights from 2006. The variable EMBI enters the equation in first differences as this increases the explanatory power of the model significantly.
} 
unexpected return, which is used to model the conditional volatility of the exchange rate in the volatility equation (4). Finally, $\sigma_{t}^{2}$ is the conditional variance and allows for the possibility of time-varying and clustering conditional volatility. The conditional distribution of the disturbance term is normal with variance $\sigma^{2}$.

29. Several features of the specification are worth noting. Equation (2) of the empirical model (the "mean" equation) analyzes changes in the exchange rate return (depreciation or appreciation against the dollar) as a function of the capital controls, controlling for other factors affecting exchange rates at a daily frequency. ${ }^{14}$ The main focus is on the estimate of $\beta_{6}$, the average impact of capital controls on the level of the exchange rate. If the imposition of capital controls led to a more depreciated (less appreciated) exchange rate, then $\beta_{6}$, the parameter of interest, should be positive and statistically significant. This would imply that the capital controls were effective in stemming the appreciation of the currency in the context of a cycle of monetary tightening.

\section{The estimation controls for financial and current account developments}

affecting short-term exchange rate movements. The interest differential aims to capture the possible impact of monetary policy and local money market conditions on the exchange rate. Yield spreads on sovereign external debt are included as a measure of country risk and foreign investor sentiment, which are potentially key determinants of foreigners' demand for local currency. We also include an index of the implied volatility of the U.S. stock market, the VIX index, which we take as a proxy for investors' perception of global financial risk. We also control for daily changes in commodity prices, to capture pressures on the exchange rate associated with current account developments.

\footnotetext{
${ }^{14}$ Given the reduced-form nature of the estimation, the framework can only identify the average response of exchange rate returns to the imposition of capital controls. It does not identify a structural relationship, or the channels through which these restrictions affect exchange rates.
} 


\section{Empirical Results}

\section{Controls and Capital Flows}

31. The econometric results suggest that the controls did not result in a reduction in aggregate non-FDI inflows (Table 2). The estimates yield a good fit for weekly data, especially for the equation estimated in net terms. They suggest that capital controls had no statistically significant impact on either gross or net non-FDI capital flows, once we control for other drivers of capital movements. ${ }^{15}$

\section{The empirical evidence also suggests that the impact of the controls varied} across different categories of inflows. The results indicate that the controls have contributed to a significant decline in foreign borrowing in both gross and net terms (Table 3). The point estimates imply that the controls led to a reduction in weekly gross foreign currency borrowing of approximately US\$44 million - about equal to their average level in the pre-controls era. The controls also led to a reduction in foreign borrowing on net terms, although only at the 10 percent confidence level. Nevertheless, the econometric results provide some evidence that the controls were effective in reducing at least one category of capital inflows. ${ }^{16}$

\section{There is no statistical evidence that the controls reduced aggregate portfolio} inflows and the bank account transfers of Colombian residents, which represent the majority of total non-FDI flows (Tables 3 and 4). The estimated effect on the drawdown of bank accounts is insignificant at standard confidence levels. In addition, the controls had no impact on total portfolio inflows, in both gross and net terms. Looking at the impact on portfolio flows by residence, the results for non-resident bond and equity flows are mixed: there does appear to be an effect on gross inflows, but not on net flows. ${ }^{17}$ For resident flows, however, the effect is unambiguously insignificant in both net and gross terms. This most likely reflects the fact that the controls did not cover domestic institutional funds, and the continued high level of inflows of foreign currency from Colombian residents and firms to purchase peso-denominated assets. Taken together, this explains why total portfolio flows appear to show little response to capital account restrictions.

\footnotetext{
${ }^{15}$ We also estimated the model with all regressors lagged one period, in an attempt to reduce simultaneity bias. The main results were unaltered. The results were also similar when the estimated over the period January 2007-July 2008. Results are available upon request.

${ }^{16}$ During the peak period of appreciation pressures — during the first four months of 2007-these inflows, in net terms, equaled $3 / 4$ percentage point of annualized GDP.

${ }^{17}$ Non-resident gross portfolio inflows averaged about 5 percent of total gross capital inflows in the pre-controls era.
} 
34. Estimates of the other covariates in the regression appear generally reasonable and consistent with past research and economic theory. An increase in interest rate spreads, a reduction in exchange rate volatility, and an increase in expected appreciation are all typically expected to lead to higher net and gross inflows. The results are consistent with these priors.

\section{In sum, the evidence on the effects of the controls on capital flows is mixed.}

Foreign borrowing appears to have declined in net terms, but only at the 10 percent confidence level. Given the modest share of foreign borrowing in total flows, however, and the statistically insignificant relationship found for other flows, the effect of the controls on total non-FDI flows is insignificant.

Table 2. Impact of Capital Controls on Non-FDI Private Capital Flows

(OLS model for weekly flow of capital: July 2006 - July 2008)

\begin{tabular}{lccc}
\hline & Dependent Variable: & \multicolumn{3}{c}{ Total Non-FDI } \\
\cline { 2 - 4 } & Net Inflows & Gross Inflows & Gross Outflows \\
\hline Explanatory Variables: & & & \\
$\alpha_{1}$ (EMBI Sovereign Spread) & -28.3 & -48.6 & -20.3 \\
$\alpha_{2}$ (Interest Rate Spread) & $42.9 * * *$ & $52.4 * *$ & 9.5 \\
$\alpha_{3}$ (Exchange Rate Volatility) & $-126.2 *$ & 166.5 & $292.7 * * *$ \\
$\alpha_{4}$ (Expected Appreciation) & $37.8 * * *$ & 23.3 & -14.5 \\
$\alpha_{5}$ (Discretionary Intervention) & $0.31 * * *$ & 0.21 & -0.08 \\
Effect of Capital Controls: & & & \\
$\alpha_{6}$ (Dummy for period 6th May 2007 onwards) & & & \\
\hline Number of Observations & 14.2 & -104.1 & -118.3 \\
R-Squared & & & \\
\hline
\end{tabular}

Asterisks denote significance of coefficients, with ***,** and * indicating significance at the $1 \%, 5 \%$ and $10 \%$ level, respectively. 
Table 3. Impact of Capital Controls on Foreign Borrowing and Drawdown of Residents' Bank Accounts Abroad (OLS model for weekly flow of capital: July 2006 - July 2008)

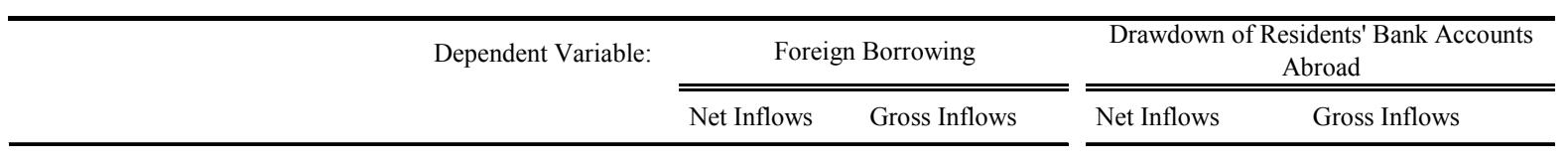

Explanatory Variables:

$\alpha_{1}$ (EMBI Sovereign Spread)

$\alpha_{2}$ (Interest Rate Spread)

$\alpha_{3}$ (Exchange Rate Volatility)

$\alpha_{4}$ (Expected Appreciation)

$\alpha_{5}$ (Discretionary Intervention)
3.6

$12.1^{* *}$

24.2

8.0

$0.1^{* * *}$
$-0.3$

$12.2^{* *}$

26.0

$9.0 *$

$0.1 *$
$-80.1 *$

Effect of Capital Controls:

$\alpha_{6}$ (Dummy for Period May 6th 2007 onwards)

$-32.5 *$

$-44.2^{* * *}$

5.7

$-50.9$

R-Squared

0.28

0.42

0.20

0.14

Asterisks denote significance of coefficients, with $* * *, * *$ and * indicating significance at the $1 \%, 5 \%$ and $10 \%$ level, respectively.

Table 4. Impact of Capital Controls on Portfolio Inflows

(OLS model for weekly flow of capital: July 2006 - July 2008)

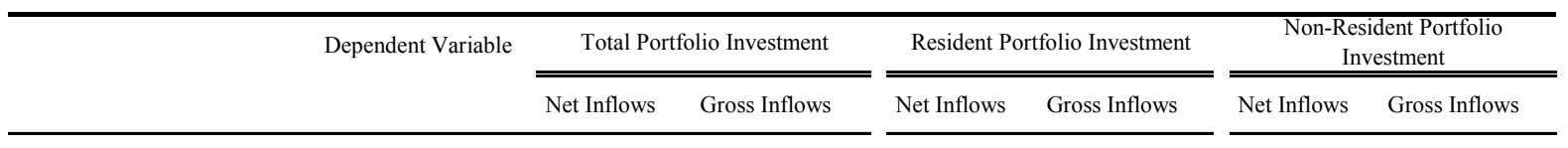

Explanatory Variables:

\begin{tabular}{|c|c|c|c|c|c|c|c|c|}
\hline$\alpha_{1}$ (EMBI Sovereign Spread) & -18.5 & 30.7 & -10.3 & 25.6 & & -6.3 & -2.0 & \\
\hline$\alpha_{2}$ (Interest Rate Spread) & -2.5 & $39.1 * * *$ & -3.9 & 33.0 & $* *$ & 0.8 & 6.7 & $* *$ \\
\hline$\alpha_{3}$ (Exchange Rate Volatility) & -6.7 & $261.4 * * *$ & 1.3 & 264.8 & $* *$ & -12.0 & 3.7 & \\
\hline$\alpha_{4}$ (Expected Appreciation) & 4.6 & $25.6 *$ & 1.4 & 21.4 & $*$ & 3.7 & 2.9 & \\
\hline$\alpha_{5}$ (Discretionary Intervention) & $0.1 *$ & 0.0 & $0.1 * *$ & -0.1 & & 0.1 & 0.1 & $* * *$ \\
\hline \multicolumn{9}{|l|}{ Effect of Capital Controls: } \\
\hline$\alpha_{6}$ (Dummy for Period May 23rd 2007 onwards) & -4.2 & -74.3 & 15.1 & -49.9 & & -13.3 & -34.6 & $* * *$ \\
\hline R-Squared & 0.28 & 0.33 & 0.07 & 0.35 & & 0.45 & 0.66 & \\
\hline
\end{tabular}

Asterisks denote significance of coefficients, with $* * *, * *$ and $*$ indicating significance at the $1 \%, 5 \%$ and $10 \%$ level, respectively. 


\section{Controls and Exchange Rates}

36. Results for estimates based on the entire sample period (July 2006-July 2008) are presented in Table 5. The first two columns present estimates of the baseline model described in equations (2)-(4). The first column reports results for the mean exchange rate equation, while the conditional variance equation estimates are presented in the second column. ${ }^{18}$ In addition, a slightly modified version of these equations was estimated to assess whether the sensitivity of the exchange rate to the explanatory variables differed under capital controls. Under this specification, we augment the model with a term that interacts the CC dummy with the interest rate differential, the VIX, EMBI, and commodity prices. If capital controls were effective in decreasing the sensitivity of the exchange rate to interest rate differentials, for example, then the coefficient in the interaction term should be positive and significant. ${ }^{19}$ If capital controls were effective in muting the transmission of global financial shocks to Colombia, then the EMBI and VIX interaction should be negative and significant.

\section{There is no statistical evidence that the capital controls have resulted in a more} depreciated exchange rate, or reduced the sensitivity of the exchange rate to interest rate differentials. Using a standard t-test, the coefficient on the capital control dummy (column 1) and the interaction term of capital controls on the interest rates differential (column 3) are found to be statistically insignificant. Capital controls have also not reduced the sensitivity of the exchange rate to global developments, as indicated by the insignificant coefficient for the interaction terms for the VIX and EMBI spreads.

38. Capital controls appear to have increased exchange rate volatility. The results indicate that the controls have had the unintended consequence of increasing the conditional volatility of exchange rate returns (column 2). This finding is consistent with Edwards and Rigobón (2005), who show that capital controls increased the unconditional volatility of the exchange rate in Chile. ${ }^{20}$

\footnotetext{
${ }^{18}$ In the results presented below, central bank intervention is expressed per US $\$ 100$ million.

${ }^{19}$ Given that an increase in interest rates typically leads to an appreciation of the currency (i.e., it has a negative coefficient), then a decrease in the sensitivity under capital controls would imply that the sign of the coefficient in the interaction term is positive. In this case, the sum of the lower-order coefficient on the interest spread and the corresponding interaction term (which measures the effect of interest rates on the exchange rate during the capital controls period) would be reduced in absolute value.

${ }^{20}$ We cannot reject the null hypothesis that all interaction terms in the variance equation in the augmented model (column 2) are jointly equal to zero. As such, the model suggests that the effect of the key explanatory variables on the variance of the exchange rate did not change with the imposition of controls.
} 
Table 5. Impact of Capital Controls on the Exchange Rate--Full Sample (July 2006-July 2008) (GARCH $(1,1)$ model for daily percentage changes in the US dollar-peso exchange rate)

\begin{tabular}{|c|c|c|c|c|c|c|}
\hline \multirow{2}{*}{ Explanatory Variables: } & \multicolumn{3}{|c|}{ Baseline Model } & & \multicolumn{2}{|c|}{ Augmented Interaction Model } \\
\hline & \multicolumn{2}{|l|}{ Mean } & \multicolumn{2}{|l|}{ Variance } & Mean & Variance \\
\hline Lagged Exchange Rate & $0.10 *$ & & --- & & $0.09 *$ & --- \\
\hline Central Bank Intervention & 0.03 & & 0.04 & & 0.08 & 0.02 \\
\hline Interest Rate Spread & -0.02 & & -0.01 & & $-0.09 *$ & -0.01 \\
\hline Change in EMBI Sovereign Spread & 2.96 & $* * *$ & 0.73 & $*$ & $2.90^{* * *}$ & 0.21 \\
\hline VIX & 0.01 & & 0.00 & & 0.00 & 0.01 \\
\hline Commodity Price Change & -0.04 & $* * *$ & -0.02 & $* *$ & $-0.04 * * *$ & $-0.04 * * *$ \\
\hline \multicolumn{7}{|l|}{ Effect of Capital Controls: } \\
\hline Dummy Capital Controls (DCC) & -0.07 & & 0.16 & ** & -0.47 & 0.03 \\
\hline DCC * Interest Rate Spread & & & & & 0.07 & 0.01 \\
\hline DCC * Change in EMBI & & & & & 0.3 & 0.53 \\
\hline DCC * VIX & & & & & 0.02 & 0.00 \\
\hline DCC * Commodity Price Change & & & & & 0.03 & 0.05 \\
\hline Number of Observations & 477 & & 477 & & 477 & 477 \\
\hline Adjusted R-Squared & 0.15 & & 0.15 & & 0.14 & 0.14 \\
\hline
\end{tabular}

39. Several factors could explain why exchange rates tended to be more variable following the introduction of capital controls. First, it may be that case that with controls on the quantity of inflows, more of the burden of adjustment falls on prices when demand for the currency changes. A weakness in this line of argumentation, however, is that the controls appear to have had no effect on the quantity of total flows affecting the exchange rate. Second, controls are likely to have segmented the foreign exchange market further, increasing conditional volatility. Third, and related to this segmentation, the capital account restrictions on nonresidents placed the pension funds in a privileged position, as they were excluded from the controls. This may have increased the importance of domestic pension funds in exchange rate market trading. For example, the average weekly trading in foreign exchange markets by pension funds (as proxied by the sum of gross portfolio inflows and outflows by residents in balanza cambiaria) increased 52 percent across periods. Given that minimum return rules provide a strong penalty for deviations from average performance in the industry and encourage herd behavior, increased activity of pension funds may have contributed to large and sudden movements of pension fund assets between peso- and foreign-currency denominated assets, exacerbating volatility. More work is needed, however, 
to shed light on the role of pension funds during capital controls and their impact on foreign exchange market conditions.

40. We also analyze how the results differ if the model is estimated over a shorter sub-sample (January 2007-July 2008) that starts during the period of most intense capital inflows. During this period, strong appreciation pressures coincided with a marked increase in capital inflows (see Figure 1). From this angle, this period provides a useful benchmark for comparing the environment immediately before the implementation of the controls. This also coincided with a period of heavy BdR intervention, and market expectations of continued intervention. During this period, there were also unusually high levels of currency derivative activity by the off-shore sector with local banks (Kamil and Reveiz, 2008). Using a sub sample of the available time period to estimate the model nevertheless has some drawbacks, as valuable information on the pre-controls regime is ignored in the estimation, and the fit of the model is inferior to that obtained from the larger sample.

\section{Estimates from the reduced sample yield largely similar results, except with} respect to the effect of the controls on the autonomy of monetary policy (Table 6). The results again suggest that the controls had no effect on average exchange rate returns, as the capital controls dummy variable (DCC) in the mean equation is not statistically different from zero. At the same time, the results for the variance equation continue to indicate that the imposition of controls led to a substantial increase in volatility. We also find, consistent with the results in the baseline sample, that the imposition of capital controls did not help to insulate the foreign exchange market from changes in global risk and EMBI spreads. However, the results for the augmented model indicate that the interactive term for the interest rate spread and the capital controls dummy is positive. ${ }^{21}$ Based on the estimates reported in Table 6, the controls enhanced the independence of monetary policy once interest spreads exceeded approximately 7 percentage points, at a 95 percent confidence level.

\footnotetext{
${ }^{21}$ Caution must be exercised when interpreting the coefficients of an interaction model. In particular, the sign, magnitude, and significance of the effect of capital controls are given by the estimate on the dummy $D C C$ and the other coefficients with interactive terms. The total effect depends on the assumed values of the explanatory variables that are part of the multiplicative terms. See Braumoeller (2004).
} 
Table 6. Impact of Capital Controls on the Exchange Rate--Sub-Sample (January 2007-July 2008)

(GARCH $(1,1)$ model for daily percentage changes in the US dollar-peso exchange rate)

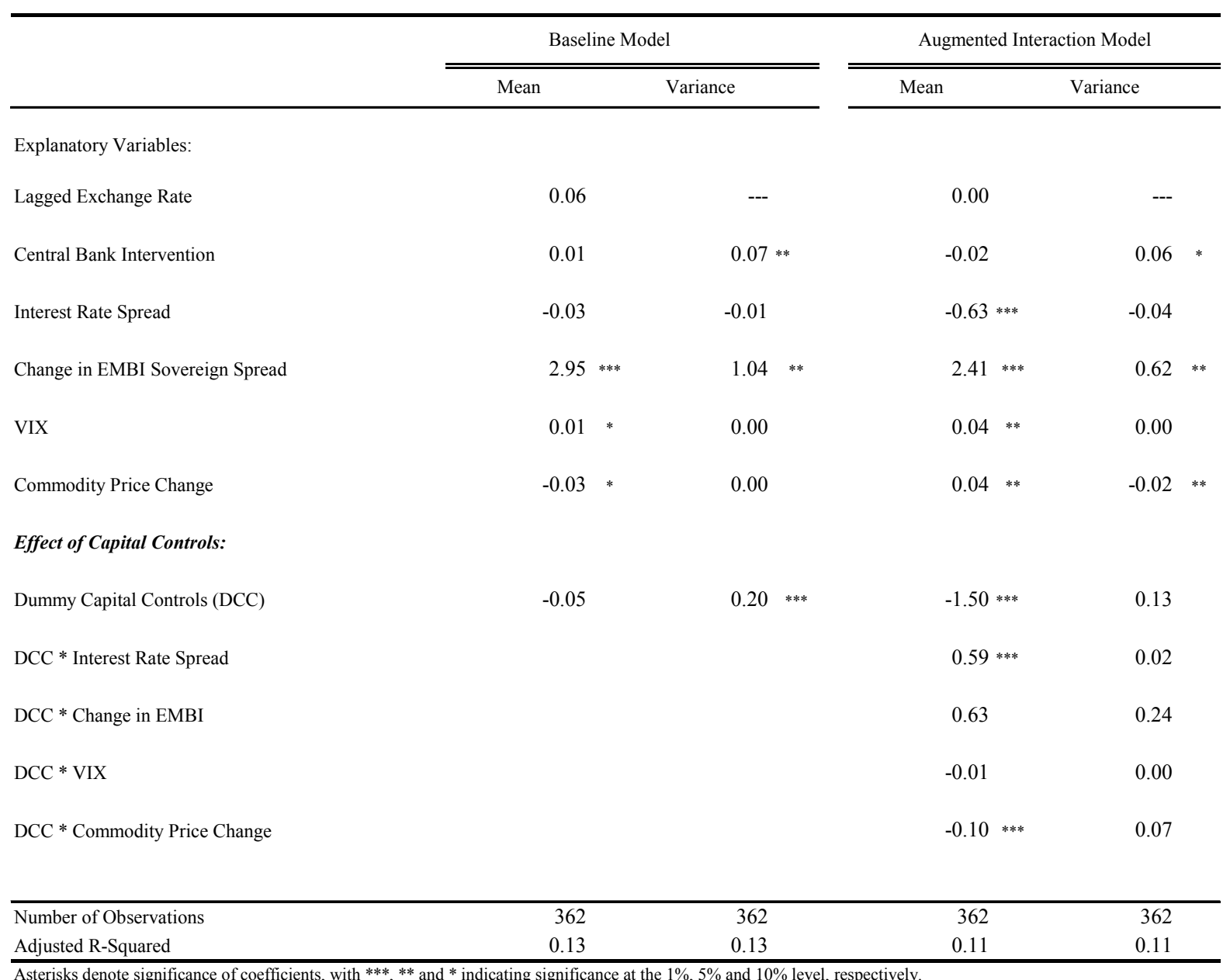

Asterisks denote significance of coefficients, with ${ }^{* * *},{ }^{* *}$ and $*$ indicating significance at the $1 \%, 5 \%$ and $10 \%$ level, respectively. 


\section{E. Conclusions and Suggestions for Future Research}

\section{Capital controls have been successful in reducing foreign borrowing, but other,} more significant categories of inflows remain high. Foreign borrowing accounted for a modest share of total capital flows in the pre-control era. For non-FDI net flows as a whole, we find the controls have had no statistically significant impact.

\section{Capital controls have not affected the level of the exchange rate, but have been} associated with an increase in volatility. Exchange rate levels do not appear to have been affected by the capital controls, regardless of the time period used for estimating the model. In addition, capital controls have not reduced the sensitivity of the exchange rate to global financial developments, suggesting that controls on capital inflows did not reduce Colombia's vulnerability to external shocks. We also consistently find that controls have actually increased the volatility of the exchange rate, which over the past two years has well exceeded the Latin American average.

\section{There is no robust evidence that the capital controls contributed to enhancing} monetary policy autonomy. The econometric estimates of the effect of capital controls on the sensitivity of the exchange rate to interest rate differentials are sensitive to the estimation period. For the entire sample period, from end-July 2006 to early July 2008, capital controls do not appear to have had an impact on the effect of interest rate differentials on exchange rate determination. If the estimation period begins in January 2007, however, capital controls are found to have a significant impact on the interface between interest rate differentials and the exchange rate.

\section{Further research is needed to fully understand the effects of the controls.}

Additional study of the channels through which carry trades are executed could provide important insights into the effectiveness of capital controls. In particular, the role of the offshore sector and pension funds in the exchange rate market could be more fully explored. Further empirical work on the effects of capital controls on the volatility of the exchange rate is also warranted. Given the sensitivity of some of the econometric results to the choice of sample, it would be also useful to extend the analysis to a longer period, especially covering the experience of the 1990s. In addition, there is room to use different measures of capital controls in future empirical work. In particular, a "tax equivalent" measure-which quantifies the implicit premium that must be paid on local returns to compensate investors for the financial costs associated with capital controls - could be utilized (Villar and Rincón, 2001; Concha and Galindo, 2008). A measure of the effect of capital controls could also be derived from information on banks' gross derivatives positions, in particular how closely these have come to the ceiling of 550 percent of gross capital. 


\section{Appendix I: The Effectiveness of Capital Controls in Colombia: Insights from Previous Research}

\section{Empirical studies find that capital controls have had mixed success in emerging market countries. ${ }^{22}$ As suggested by Magud and Reinhart (2007), the effectiveness of capital} controls can be assessed from the standpoint of their ability to (1) limit capital inflows; (2) change the composition of flows (in particular, by shifting flows to long-term assets); (3) alleviate real exchange rate pressures; and (4) provide more independence for monetary policy by severing the link between domestic and international interest rates. Studies in this area have confronted a minefield of methodological issues, and not always with great success (Magud and Reinhart, 2007; International Monetary Fund, 2007). Among these challenges is the difficulty of isolating the effects of capital controls per se on capital flows and exchange rates, as well as endogeneity issues. The area where capital controls have been most successful is in providing more autonomy for monetary policy and altering the composition of capital inflows, while success on reducing the volume of inflows and reducing exchange rate pressures has been mixed.

Previous research on the experience of Colombia in the 1990s with capital controls is broadly consistent with these findings. Most studies, but not all, have concluded that capital controls have been ineffective in reducing inflows or influencing the real exchange rate, but did affect the composition of inflows and monetary policy autonomy. ${ }^{23}$ Cárdenas and Barrera (1997) find that capital controls between 1985 and 1995 had no impact on total capital flows but changed their composition. A similar finding is reported in Rocha and Mesa (1998) who argue that capital controls reduced the short-term interest rate differential, increasing medium- and long-term foreign debt. Using a data set that covers the period between 1993 and 1998, Ocampo and Tovar $(1999,2003)$ argue that capital controls diminished not only short-term but also long-term capital flows, while Rincón (2000) finds that capital controls reduced short-term flows. Using a similar data set, Villar and Rincón (2001) find that capital controls allowed the authorities to increase domestic real interest rates without creating pressures for real appreciation of the peso.

Three recent studies on the 2007 controls arrive at mixed results. Cardenas (2007) examines the effects of the 2007 controls, using weekly data on total capital inflows on assets of more than one year of maturity. Using ordinary least squares, and controlling for other determinants of inflows such as interest rate differentials, he finds that controls had no

\footnotetext{
${ }^{22}$ For cross country reviews of the evidence on capital controls, see also IMF (2007), Magud and Reinhart (2007), and Edwards (2007).

${ }^{23}$ See also Uribe (2005) for a review of the Colombian literature. For a minority view-arguing that capital controls were effective in influencing both short and long-term capital flows - see David (2007).
} 
statistically significant effect on capital inflows. This approach, however, may be biased towards finding that capital controls are ineffective, as the dependent variable - total capital inflows of more than one year-misses the effect of controls on inflows seeking to purchase short-term assets. In addition, the inclusion of foreign direct investment (FDI) is problematic, as FDI flows are unlikely to be influenced by the same factors that drive portfolio inflows, such as interest rate differentials. As such, the model is unlikely to find that the controls affect total inflows, even if they have a tangible effect on portfolio inflows. Galindo (2007) and Concha and Galindo (2008), using a vector error correction model (VECM) with monthly data, find that capital controls had a significant effect on short-term capital inflows, but not the real exchange rate. They find that capital controls do, however, reduce the volatility of the real exchange rate. 


\section{References}

Bollerslev, Tim, and Jeffrey Wooldridge, 1992, "Quasi-Maximum Likelihood Estimation and Inference in Dynamic Models with Time-Varying Convariances," Econometric Reviews, Taylor and Francis Journals, Vol. 11, pp. 143-172.

Braumoeller, Bear, 2004, "Hypothesis Testing and Multiplicative Interaction Terms," International Organization, Vol. 58, pp. 807-820.

Cardenas, Mauricio, and Felipe Barrera, 1997, "On the Effectiveness of Capital Controls: The Experience of Colombia during the 1990s," Journal of Development Economics, Vol. 54, pp. 27-57. ,2007, “Controles de Capitales en Colombia: ¿Funcionan o No?” Debate de Coyuntura Económica, December (Bogotá, Colombia, Fedesarrollo).

Concha, Alvaro, and Arturo Galindo, 2008, “An Assessment of Another Decade of Capital Controls in Colombia: 1998-2008.” Paper presented at the XIII LACEA Meeting (Rio de Janeiro: Brazil).

David, Antonio, 2007, “Are Price-Based Capital Account Regulations Effective in Developing Countries?,” World Bank Policy Research Paper Working Paper No. 4175 (March).

Edwards, Sebastián, ed., 2007, Capital Controls and Capital Flows in Emerging Economies: Policies, Practices, and Consequences (Chicago: The University of Chicago Press).

Edwards, Sebastián, and Roberto Rigobón, 2005, “Capital Controls, Exchange Rate Volatility and External Vulnerability,” NBER Working Paper No. W11434 (June).

Galindo, Arturo 2007, “Controles de Capitales en Colombia: ¿Funcionan o No?,” Debate de Coyuntura Económico, December (Bogotá, Colombia: Fedesarrollo).

Gómez, Carlos, Diego Jara, and Andrés Murcia, 2006, “Impacto de Las Operaciones de Los Fondos de Pensiones Obligatorias en Los Mercados Financieros Colombianos," Borradores de Economía No. 406 (Bogotá, Colombia: Banco de la República de Colombia).

International Monetary Fund, 2007, World Economic Outlook, October (Washington: International Monetary Fund).

Kamil, Herman, 2008, "Is Central Bank Intervention Effective Under Inflation Targeting Regimes? The Case of Colombia," IMF Working Paper 08/88 (Washington: International Monetary Fund). 
, and A. Reveiz, 2008, “Carry Trades, Special Vehicle Purposes and Derivatives Markets in Colombia: Mechanisms and Policy Implications," (Unpublished, Washington: International Monetary Fund).

Magud, Nicolas, and Carmen Reinhart, 2007, "Capital Controls: An Evaluation,” in S. Edwards, ed., Capital Controls and Capital Flows in Emerging Economies: Policies, Practices, and Consequences (Chicago: The University of Chicago Press).

Ocampo, José Antonio, and Camilo Ernesto Tovar, 1999, "Price-Based Capital Account Regulations: The Colombian Experience," CEPAL, Serie Financiamento del Desarrollo (Santiago, Chile). , 2003, "Colombia's Experience with Reserve Requirements on Capital Inflows," CEPAL Review, No. 81 (December), pp. 7-31.

Rocha, Ricardo, and Ricardo Mesa, 1998, "Flujos Internacionales de Capital en Colombia: Un Enfoque de Portafolio," Archivos de Macroeconomia, No. 78 (Bogotá, Colombia: Departamento Nacional de Planeación)

Rincón, Hernán, 2000, “Efectividad del Control a Los Flujos de Capital: Un Reexamen Empírico de la Experiencia Reciente en Colombia," Revista de Economía de la Universidad del Rosario (February), pp. 15-36.

Uribe, José Dario, 2005, “Capital Controls and Foreign Exchange Market Intervention in Colombia,” BIS Paper No. 23 (May), pp. 128-40.

Vargas, Hernando, and Carlos Varela, 2008, "Capital Flows and Financial Assets in Colombia: Recent Behavior, Consequences and Challenges for the Central Bank," Borradores de Economía No. 502 (Bogotá, Colombia: Banco de la República de Colombia).

Villar, Leonardo, and Hernán Rincón, 2001, "Flujos de capital y regímenes cambiarios en la década de los 90," Ensayos sobre Política Económica, No. 39 (Bogotá, Colombia: Banco de la República de Colombia). 